NBER WORKING PAPER SERIES

\begin{abstract}
IMPLICATIONS FOR THE ADJUSTMENT PROCESS OF INTERNATIONAL ASSET RISKS: EXCHANGE CONTROLS, INTERVENTION AND POLICY RISK, AND SOVEREIGN RISK
\end{abstract}

Willem H. Buiter

Working Paper No. $\underline{516}$

\author{
NATIONAL BUREAU OF ECONOMIC RESEARCH \\ 1050 Massachusetts Avenue \\ Cambridge MA 02138
}

July 1980

This paper was given at the Conference on Internationalization of Financial Markets and National Economic Policy, April 10-1l at N.Y.U. I would like to thank Robert Stern and Clas Wihlborg for detailed comments on an earlier version. Financial support from an N.S.F. Research Grant is gratefully acknowledged. The research reported here is part of the NBER's research program in International Studies. Any opinions expressed are those of the author and not those of the National Bureau of Economic Research. 


\section{Implications for the Adjustment Process \\ of International Asset Risks: \\ Exchange Controls, Intervention and Policy Risks, \\ and Sovereign Risk}

ABSTRACT

This paper analyzes the implications of international asset risks for the operation of the international adjustment process, with special emphasis on the scope for monetary policy. After a brief review of actual practice. in the evaluation of country risk, the paper discusses a number of modifications in the standard theory of efficient international financial markets that are necessitated by the existence of country risk. For macroeconomic policy, the major implications are that domestic and foreign assets become imperfect substitutes and that world demand for domestic assets is likely to be less than perfectly elastic, even in the "small country" case." Even under a fixed exchange rate, a measure of domestic control over domestic interest rates therefore exists.

Willem H. Buiter Department of Economias. University of Bristol Alfred Marshall Building 40 Berkeley Square Bristol, BS8 1HY England

Tel.: 0272-24161 
I Introduction

II The measurement of country risk.

III The standard economic view of intemational financial markets.

IV The implications of political risk for the modelling of international financial markets.

$\mathrm{V}$ The implications of political risk for the international adjustment process with particular reference to the role of monetary policy.

VI Conclusion . 


\section{Introduction}

International asset risks are those risks that distinguish an international loan from a domestic loan which is otherwise the same in all respects (size, maturity, repayment schedule and even currency denomination). This loan can be for portfolio investment or for direct investment, to and from private or public agents. The importance of international asset risk or country risk is recognized by the financial community and by governments. For instance, Citicorp, stating that country risk is the "principal difference between domestic and international business" and that "Country risk exists whenever Citicorp lends, places or invests funds across a country border", $2 /$ devotes a sizeable section of its 1975 Annual Report to its international lending operations. Alexander Mc.W. Wolfe, Jr. defines country risk as "... the primary additional component which distinguishes an international loan from a domestic loan. Regardless of whether the borrower happens to be a government, quasi-public company or private entity, an appraisal of economic and political factors becomes a vital element in evaluating creditworthiness or country risk." ${ }^{3 /}$ Finally, wihlborg defines country risk as uncertainty about laws, regulations and property rights that depend solely on the country of issue of a financial asset (Wihlborg [1978, p. 5]). In recent years attention has been focussed mainly on lending by commercial banks in the western world, especially the U.S.A., to L.D.C.'s. The rapid expansion of this category of international lending has generated fears about the possibility of default. As the recent freeze on official Iranian assets in the U.S.A. has demonstrated, however, sovereign risk can affect even those who lend to the most developed country in the international financial community. The precarious external debt positions of countries as varied as Poland, Turkey, Zaire, Yugoslavia and Indonesia show that political risk can be a major factor regardless of ideology, religion, or stage of development. 


\section{Table 1}

\section{Classification of types of risk}

Domestic

$$
\text { Economic risk - specific }
$$$$
\text { - general }
$$

Political risk (sovereign risk)

- wars

- coups, revolutions

- expropriation

- discretionary default debt moratoria
Foreign

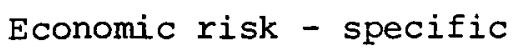
debt moratoria

Social risk

- regional, tribal or class conflict, social unrest etc.

Intervention and policy risk

Intervention and policy risk

Legal risk

- jurisdictional disputes

- disputes between borrowers and lenders
- regional, tribal or class conflict, social unrest etc. 
Table 1 presents a simple classification of the kinds of risk likely to be encountered by a person or institution planning to invest funds. While the boundaries between the various categories are often vague, even conceptually, the classification is quite comprehensive. The first important thing to note is that $a$ every kind of risk that is likely to concern investors is likely to be present with domestic investment as with foreign investment. Important differences in degree do often exist, however. Economic and financial risk can be specific, related to the economic performance of a specific investment, project, sector or industry, or general, related to a country's economic performance with respect to inflation, real output growth and external balance. Since economic policy is a major determinant of specific and general economic performance, economic risk and political risk, or "sovereign risk" are inextricably bound up. "Sovereign risks" are the risks associated with adverse political developments--wars, coups, revolutions, expropriation of foreign ownership, discretionary defaults or discretionary debt moratoria etc. Political and economic risks are themselves functions of wider social and cultural uncertainties. Intervention and policy risk can be viewed as the less spectacular forms of sovereign risk. Even broad macroeconomic fiscal and monetary stabilization policy may affect the return on certain investments. Together with specific forms of market intervention (price controls, credit ceilings) and changes in allocative or structural policies (tax credits, depreciation allowances, subsidies, tariffs, quotas) they constitute intervention and policy risk. Sovereign risk and intervention and policy risk merge into legal risk. Changes in contract law, liability and disclosure laws, problems of conflicting and overlapping jurisdictions, methods for resolving disputes between lenders and borrowers, legal restrictions on the repatriation of dividends and profits of foreign investors and other forms of exchange control, all affect the rate of return to the investor. A measure of the variety and scope of exchange controls is the Annual Report on Exchange Arrangements and Exchange Restrictions issued by the IMF, which for 1979 ran to 470 pages (IMF [1979]). 
It should be noted that country risk is typically asymmetric: the degree of risk depends, for a given borrower, on the country of habitat (or nationality) of the lender, or for a given lender, on the country of habitat (or nationality) of the borrower. Country risk also often is not a zero-sum risk in which gains to borrowers necessarily equal losses to lenders. To the extent that the risk "game" has a negative sum it cannot be diversified completely. Also, since political risks are to a greater or lesser extent under the control of the participants in the international loan market, there are obvious moral hazard problems limiting the extent of coverage against political risk.

Exchange risk and political risk

This paper focuses on the implications of political risk in the most general sense (i.e. including sovereign risk, intervention and policy risk and legal risk) for the modeling of international financial markets and for the international adjustment mechanism.

In its widest possible interpretation, political risk should include a significant share of any exchange risk faced by an investor. Government actions affect the exchange rate either directly, through exchange rate pegging or other more flexible forms of exchange rate management or indirectly, by altering the proximate determinants of exchange rates determined in markets without direct foreign exchange market intervention. The current and anticipated future course of monetary policy and the current and prospective future magnitudes of the public sector borrowing requirement are among the 
major channels through which governments affect the behavior of spot and forward exchange rates, even in a "freely floating" exchange rate regime. Exchange risk, in the absence of political risk and without adjustment costs in international financial markets, has been studied exhaustively by economists. A recent elegant statement of the extent to which exchange rate risk can be diversified can be found in Frankel [1979]. I shall for the most part ignore exchange risk and concentrate on those risks associated with international lending and borrowing that would exist even in a world with rigidly fixed exchange rates which are confidently expected to remain that way forever. Alternatively, one could interpret the analysis as applying to a world in which lenders and borrowers of any nationality can issue or purchase financial claims denominated in any currency or basket of currencies, and in which, because Frankel's conditions for complete diversifiability are satisfied there remains no residual exchange risk. 5/

Finally, it should be noted that the "nationality vector" of an international loan can have a very large number of components indeed. Table 2 provides a summary of the most important dimensions.

Table 2 Some "nationality dimensions" of an international loan

- Nationality of lender

- Country of residence of lender

- Nationality of borrower

- Country of residence of borrower

- Location of market (i.e. place of issue)

- Currency denomination of loan 
E.g. the German branch of an American bank could lend, in London, to the Dutch branch of the state-owned Bank of I.D.C.-x, with the loan denominated in S.D.R.' $s$.

The remainder of the paper is laid out as follows. Section II briefly considers actual practice in the evaluation of country risk. Section III reviews the standard economic view of international financial markets-an application of the theory of efficient capital markets. Section IV studies how this view of international financial markets must be modified when country risk is introduced in a number of different ways. Section $V$ considers the implications of the analysis for the operation of the international adjustment process, with special emphasis on the scope for monetary policy.

\section{The measurement of country risk}

Unless there is a dramatic case of market failure in the markets for information, the expenditure of resources on the assessment and evaluation of country risk should be a useful indicator of the importance attributed to country risk by investors and financial managers. While there is a large literature, in book and journal article form on the management of foreign exchange risk (e.g. Aliber [1973, 1975, 1978], Jacque [1978]). written work on country risk analysis lives mainly in internal memoranda and pamphlets written by non-academic economists and other practitioners of the art (but see Zuheir Sofia [1978] and Mc.W. Wolf [1975]). A study of the available literature suggests that following features are shared by most applied studies of country risk. (See e.g. Blask [1976], Harberger 
[1976], Maroni [1977], Frank and Clive [1971], Feder and Just [1977], Nagy [1978], Fisk and Rimlinger [1979], Bench [1977], Schuler [1977], Sargen (1977], Goodman [1977], Puz [1978], Export-Import Bank Policy Analysis Staff [1977], MC.W. Wolf [1975], Eaton and Gersovitz [1979, 1980]).

1) What potential lenders attempt to assess is the probability of the borrower defaulting on the loan. Both "discretionary" default (sovereign risk) and "bad luck" default (economic and financial risk) are evaluated. In practice default is but one position on a continuum of different kinds and degrees of breach of contract (or "arrearages and delinquencies"), ranging from a strictly temporary moratorium on debt service, accompanied by a rescheduling of debt payments, all the way to a complete and permanent repudiation of all debt obligations (interest and repayment of principal). Examples of this most extreme kind of default are the refusal of the Soviet government to honcr financial commitments incurred under the Tsarist regime and the unwillingness of Castro Cuba to honor the obligations of the Battista era. Country risk analysis consists of formal and informal, qualitative and quantitative study of the observable (if not always measurable) correlates the

of default risk. E.g. "checklist" system of assessing risk of future debt servicing difficulties is used by five out of thirty-seven U.S. banks surveyed in 1977 by the Export-Import Bank. The system consists in assigning a cardinal rating to each country with respect to a number of indicators (see Table 3 ). These ratings for the various indicators are then averaged into a summary statistic for each country, using a common set of weights. This summary statistic becomesone of the inputs into the final risk evaluation. Other banks and institutions make use, in a less formal way, of similar 
information in their assessment of country risk. Outside the banks,

academic economists have applied more formal statistical methods (regression analysis, discriminant analysis etc.) to the assessment of country risk.

(Frank and Clive [1971], Feder and Just [1977], Sargen [1977], Export-Import Bank Policy Analysis Staff [1977], Eaton and Gersovitz [1979-80].

$\underline{\text { Table } 3}$

Indicators included in checklist system of American banks, surveyed by Export-Import Bank, that used such a system.

Variable

I - Variables relating to the internal economy

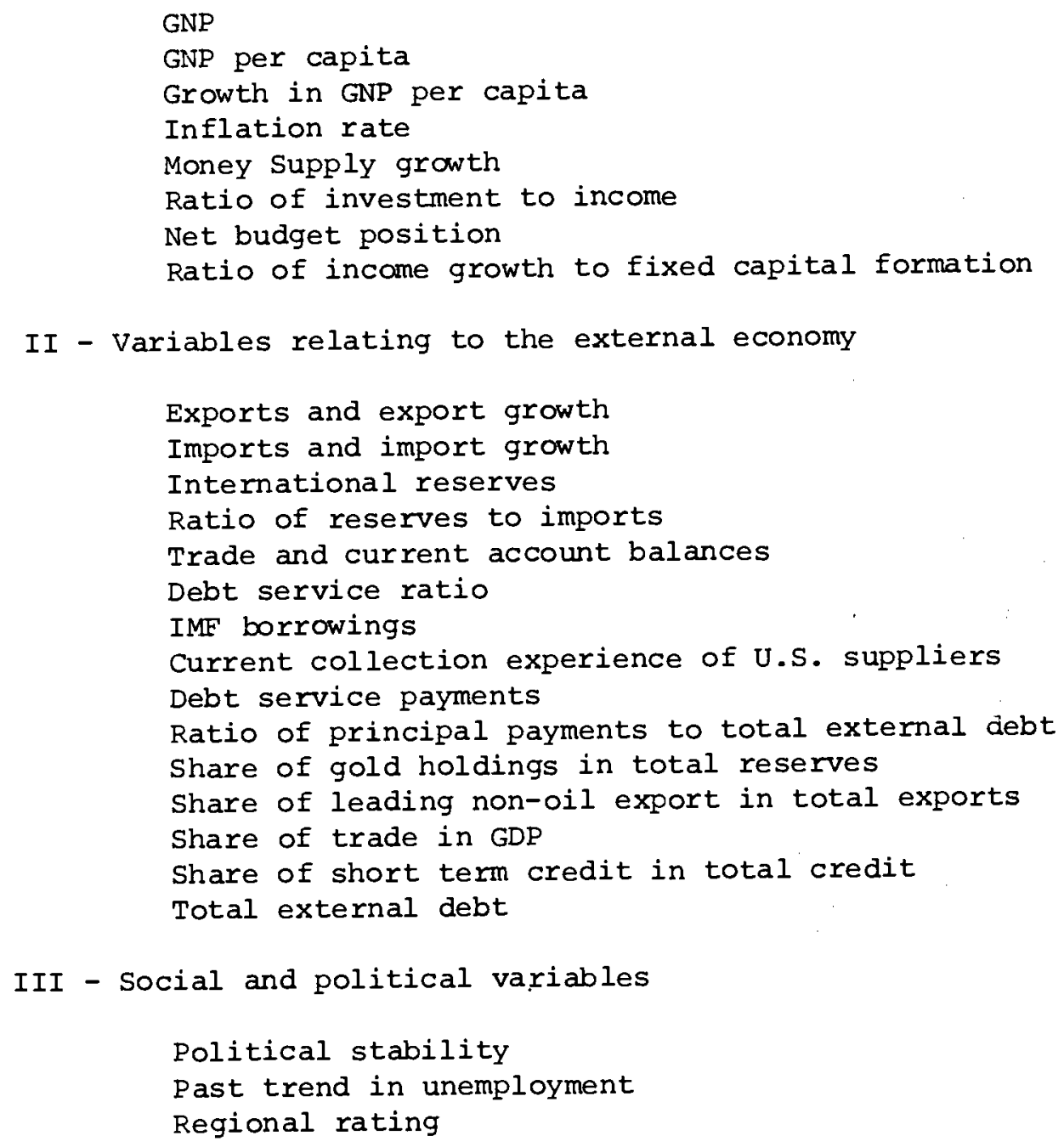

Source: Goodman [1977]. 
2) The analysis is done on a country-by-country basis. "When assessing the country risk of a particular nation, it should be analysed separately and treated on its own merit. No two countries are exactly alike." (Zuheir Sofia [1978]. If this statement, and others like it, referred only to the need to recognize the uniqueness in space and time of every specific country or lending project, it would be trite but unobjectionable. It seems to reflect, however, a failure to recognize one of the more robust implications of portfolio analysis, that is the need to look at a lending institution's entire portfolio of assets and liabilities rather than at each project or loan separately

3) The procedures for evaluating country credit risk seem on the whole to be rather crude and unsatisfactory. This negative view appears to be shared even by the major U.S. banks that account for much of the analysis. Especially striking is the apparent reluctance to systematically test the ex-post predictive accuracy of the country risk evaluation procedures. Even where an attempt is made to analyse the available data systematically, the absence of a clear theoretical framework makes the interpretation of the results a very uncertain and ambiguous exercise. Two examples will suffice to illustrate this point.

The policy analysis staff of the Export-Import Bank used logit analysis to solve the binary choice problem as to whether or not a given country will reschedule (Export-Import Bank Policy Analysis Staff [1977]). The probability of a country rescheduling was related to the following set of explanatory variables. 1) percentage change in the CPI (with a positive coefficient), 2) reserve position in the IMF divided by imports (with a negative coefficient), a measure of the country's ability to pay its international bills, 3) exports divided by GDP (with a negative coefficient), a measure of "a country's foreign exchange generating ability subject to the total demands of the economy", 4) disbursed debt outstanding divided by exports, a measure of the 
country's "overall debt situation", (with a positive coefficient, 5) largest export divided by total vulnerability of a country's foreign exchange revenues to external price fluctuations, 6) international reserves divided by imports (with a negative coefficient), a measure of the "international financial stability of the nation" .

The second example is a study by sargen [1977] using discriminant analysis to classify a group of L.D.C. countries into a rescheduling and a nonrescheduling category. The explanatory variables were 1) debt service ratio, 2) reserve-import ratio,3) export growth rate,4) growth rate of real GNP, 5) level of real GNP per capita, 6) rate of change of the CPI, 7) growth of $M_{1}$, a "measure of relative purchasing power parity".

Both these studies and others not mentioned here suffer from the absence of an explicit model of default. Specifically, they cannot differentiate between "bad-luck" default and "discretionary" or "dishonest" default. If the r.h.s. variables in these regressions measure any relevant aspect of the default decision, they try to assess the borrower's current and future opportunity set, i.e. his ability to repay. This is adequate for a full analysis of default only if countries never default when they have the economic ability to pay their debt obligations. However, a solvent borrower may choose to default if the expected benefit from doing so exceeds the anticipated current and future costs. These costs are mainly reflected in the defaulting country's inability to have access to international credit in the future. This will be a serious constraint if its exports and imports are large, variable and uncertain. While export variability may therefore make it hard for a country to service its debt obligations when exports are temporarily (and/or unexpectedly) low, that same variability provides an additional incentive not to fall in arrears on its external debt. This more complete view of debt repudiation has been developed and implemented empirically by Eaton and Gersovitz [1979, 1980], who model and estimate optimal borrowing and default 
behavior by debtors and optimal credit rationing by lenders. It would seem that this approach should lead to better predictions than the ad hoc approaches adopted in the earlier literature.

4) The occurrence of "arrearages and delinguencies" since World War II is a comparatively rare event. As of september 30, 1978 total arrearages and delinquencies on post-World War II debt of U.S. Government agencies was $\$ 612$ million, compared with a total post-World War II foreign debt on the books of the U.S. government on that date of $\$ 45.7$ billion. (Bergsten [1979]). Data on non-guaranteed private loans are much harder to come by. A dramatic recent example is the failure of Zaire to pay interest on its loans since June 1975. It is estimated that private debt to commercial banks up to $\$ 930.5$ million may have been affected by this (Zuheir sofia [1978]). In Zaire's case default was not "discretionary" but reflected "bad luck" and bad management. Given the ability to pay, the incentive to default is an increasing function of the volume of outstanding debt and a decreasing function of a country's likely future need for access to international credit markets. The relative infrequency of default may be a reflection of the superior country risk analysis of public and private international lending agencies. This seems unlikely, given the quality of most of the work that I have seen. It is more likely to reflect the high cost of default, in the form of loss of access to the international capital markets. Unlike bankrupt individuals, countries can't relocate and open shop again under a new name. It would therefore seem useful to do a careful cost-benefit analysis of the resources devoted to the evaluation of country risk. 
III. The Standard Economic View of International Financial Markets

When modelling behavior under uncertainty, professional economists tend to simply postulate the existence of (objective or subjective) probability distribution functions for the unknown current and future events whose outcomes will determine the degree of success or failure of some set of economic decisions. At its most general level the theory applies the same paradigm--expected utility maximization--to household consumption, laborleisure and portfolio allocation decisions as to the financial and real investment decisions of the business sector. Porfolio theory--in its mean-variance incarnation--has become established as the highest form of Lational financial decision-making under uncertainty. This holds for international as for domestic investment and portfolio management. Rather less attention has been paid by economists to the exact nature of the risks faced by different economic agents, the working hypothesis apparently being that there is a natural division of labor between the practical man of affairs who evaluates the risks and returns of the various projects in his domain, and the economist who uses the fruits of this labor to compute the Markowitz frontier. Unconstrained by any perceived need to relate their assumed distributions of risks and returns to the realities of practical portfolio management, economists have tended to go the way of analytical least resistance. In the field of international finance this has resulted in a stylized view of the world that I shall call efficient international capital markets theory. Efficient international capital markets are characterized by a number of properties.

1) Instantaneous and continuous market clearing. Given the information available to all actual and potential market participants, given their expectations of the future and given the other state variables (exogenous and predetermined) that together fully describe the state of the system (the set of international financial markets), asset prices and rates of return always assume the values required to equate demand and supply in all 
2) Competitiveness of all markets. The implicit or explicit assumption of free entry and many actual or potential traders implies that all market participants are price takers. The demands and supplies that are kept in continuous balances are the notional demands of competitive, expected utility or market value maximizing agents.

3) Rational expectations and incomplete but not asymetric information. The anticipations of all agents are based on subjective probability density functions of future returns that are the same as the true, objective probability density functions generating these uncertain returns. Since the theory seldom goes beyond the first two moments of the distribution of returns, this assumption means in practice that all lenders and borrowers know the correct means vector and variance-covariance matrix of asset returns. This assumption that all agents have the same (albeit incomplete) information will turn out to be very restrictive and very important.

4) All assets are perfectly divisible and perfectly "liquid", i.e. all assets are marketable in any quantity at parametric prices. There are no transactions costs (including costs of gathering information) and m restrictions on short sales.

5) Each country issues an asset that is risk free in terms of that country's currency. Investors can borrow or lend any amount at these risk-free rates. Except for their currency denomination, these risk-free assets are identical in all respects.

A market with properties 1) - 4) is informationally efficient in the sense that the prices determined in such a market "fully reflect" the available, homogenous information. Property 5) is not essential for market efficiency but is the simplest way to generate one of the important propositions of international financial market theory, i.e. interest parity. I shall not be concerned with the issue of the extent to which prices in markets with non-homogenous asymmetric information are efficient aggregators of this diverse, heterogenous information (on this see e.g. Grossman 
Some of the important implications of efficient international capital markets theory are the following.

a) For the risk-free assets mentioned under property 5), international interest parity prevails: the domestic interest, $r$, equals the foreign interest rate $r *$ plus the forward discount on the domestic currency, $\varepsilon: r=r^{*}+\varepsilon$.

b) International investors can and will engage in instantaneous stockshift rebalancing of their portfolios between domestic and foreign assets in response to new information.

c) Even with risk-averse investors, the forward exchange rate will be an unbiased, mean squared error miminizing predictor of the future spot rate with the appropriate maturity, if the conditions stated by Frankel [1979] are satisfied. These assumptions were 1) rates of return on nominal assets are independent of rates of return on real assets and 2) there are no 'outside' assets denominated in the currency of the country that issues them.

d) The "small country" assumption that the interest rate on its own liabilities is parametric to a borrowing country (i.e. that there is an infinitely elastic world demand for the country's debt) is an appropriate one for a large number of actual 'small' countries, i.e. countries with a small share of world wealth, GNP and trade (although not, presumably for the U.S.A.).

e) Foreign exchange market intervention (sales and purchases of international assets by central banks) is irrelevant for the real economy to the extent that it is anticipated and harmful to the extent that it is unanticipated.

f) Capital controls and exchange controls lower potential welfare.

g) Monetary (and fiscal) policy cannot affect domestic interest rates except to the extent that it affects the forward premium. Under fixed exchange rates, therefore, domestic interest rates are independent of domestic monetary and fiscal policy (other than differential tax treatment of domestic and foreign interest income etc.). In the next section, I shall describe some of the ways in which propositions a) through g) must be modified in the presence of political risk. 
IV. The Implications of Political Risk for the Modelling of International Financial Markets

IV.1 The demise of interest parity in the presence of political risk

The proposition that political risk, especially default risk, causes departures from international interest parity -- equality of interest rates on domestic and foreign assets after allowing for the cost of forward cover -is well-established (Kenen [1965], Kouri [1976], Eaton [1978]). The following example is taken from Eaton [1978].

Consider an investor from country 1 who maximizes the expected utility of terminal wealth $w_{t+l}$ by optimally allocating his initial wealth $w_{t}$ between domestic assets paying a safe nominal return $r_{t}$ and foreign assets earning a rate of return $r_{t}^{*}$ in terms of foreign currency (country 2) with probability $Q^{*}$ and a rate of return -1 with probability $1-Q^{*}$. 1-Q* is the foreign debtor's probability of default. $e^{s}$ denotes the logarithm of the spot exchange rate in period $t, e^{f} t$ the logarithm of the one period forward exchange rate in period $t$. The investor from country 1 allocates a fraction $\lambda^{F}$ of his initial wealth to the bond of country 1 . A fraction $\lambda^{s}$ of his initial wealth is used to purchase country 2's currency forward. The balance sheet of this investor is given below, in Table IV. 1 together with the expressions for the returns on his investments. There is assumed to be no risk of default on forward contracts. At time $t$ the forward exchange rate $e_{t+l}^{s}$ is a random variable with mean $\bar{e}_{t+l}^{s}$ and variance $\sigma^{2}$. For our purposes it is immaterial whether the investor's utility is a function of nominal wealth $w_{t}$ or of real wealth $w_{t} / p_{t}$, where $p_{t}$ is the appropriate general price level index. For simplicity I shall consider the case where $w_{t+l}$ is the appropriate argument in the utility function. The investor maximizes $E\left(U\left(W_{t+l}\right)\right), U^{\prime}>0, U^{\prime \prime} \leqslant 0$, where $W_{t+1}$ is given by

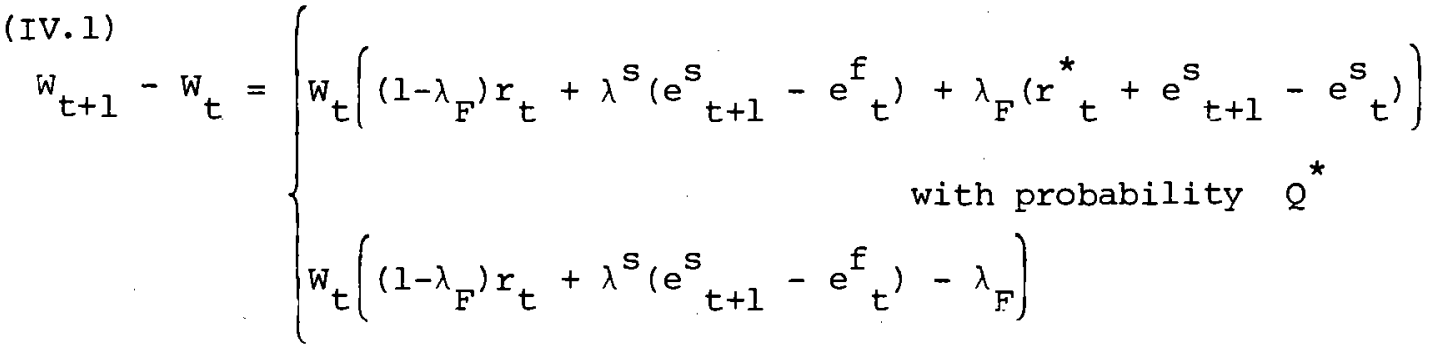

$$
\begin{aligned}
& \text { with probability } 1-Q^{*} \text {. }
\end{aligned}
$$


Table IV. 1

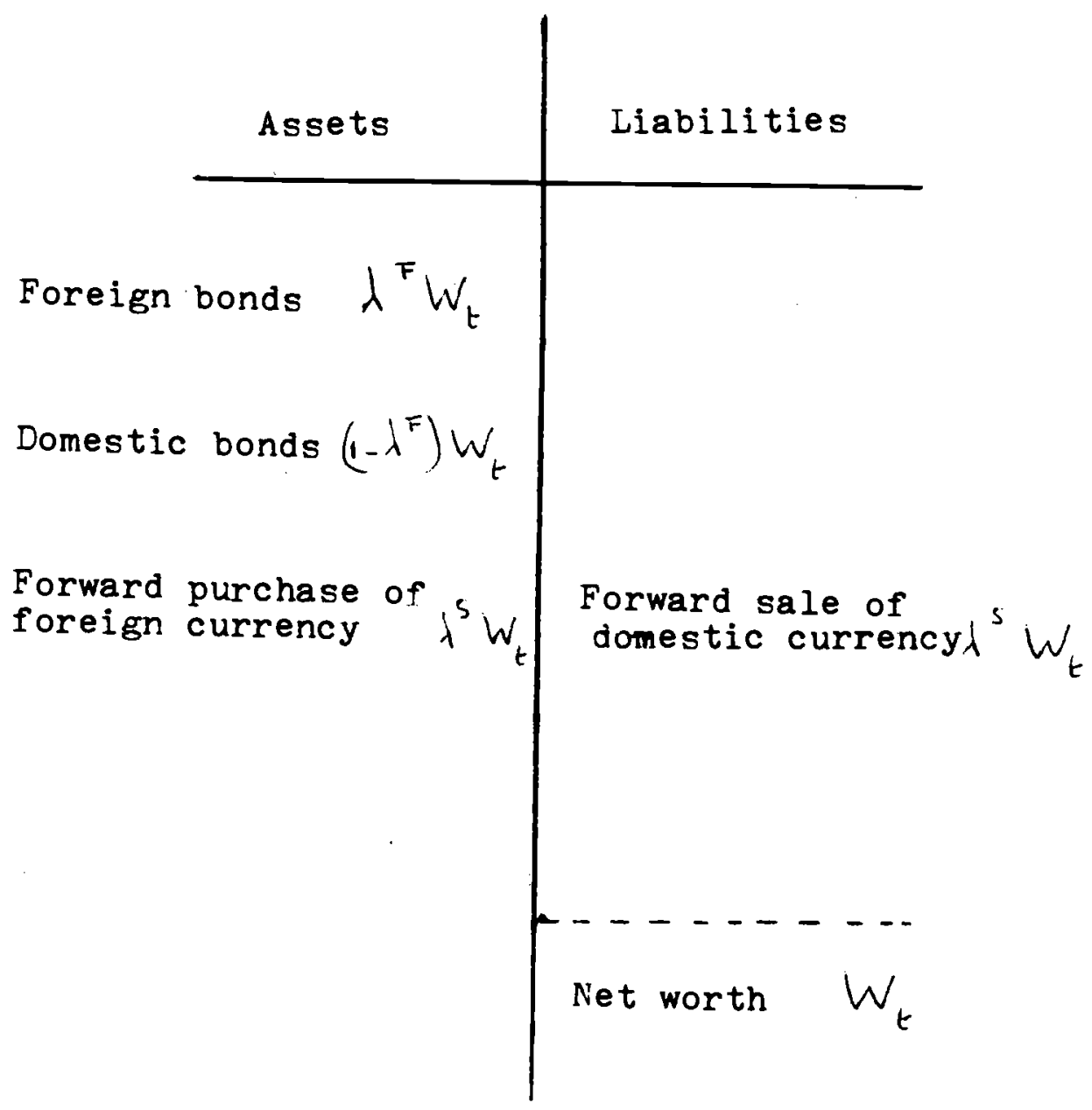

Rate of return on the foreign bond: $r_{t}^{*}+e_{t+1}^{s}-e_{t}^{s}$ with probability $Q^{*}$ $-1$ with probability $1-Q^{*}$

Rate of return on the domestic bond: $r_{t}$ with probability 1 Rate of return on the forward contract: $e_{t+1}^{s}-e_{t}^{f}$ with probability 1 
By taking a second-order Taylor series approximation at $w_{t}$ we can express expected utility as:

$(I V .2) E\left(U\left(W_{t+I}\right)\right) \cong U\left(W_{t}\right)+U^{\prime}\left(W_{t}\right) E\left(W_{t+I}-W_{t}\right)+\frac{1}{2} U^{\prime \prime}\left(W_{t}\right) E\left(W_{t+I}-W_{t}\right)^{2}$

The first-order conditions for a maximum can be rewritten as:

(IV.3) $\lambda^{s}=\frac{\bar{e}_{t+1}^{s}-e^{f} t}{R \sigma_{e}^{2}}-Q * \lambda^{F}$.

$\left(I V\right.$. 4) $\lambda^{F}=\left(\bar{r}_{t}^{*}-r_{t}\right)\left[R Q^{*}\left(I-Q^{*}\right)\left(I+\sigma_{e}^{2}\right)\right]^{-1}$

with

(IV. 5a) $\quad \bar{r}_{t}^{*}=\left(r_{t}^{*}+e_{t}^{f}-e_{t}^{s}\right) Q^{*}-\left(I-Q^{*}\right)$.

(IV.5b) $\quad R=-U^{\prime \prime}\left(W_{t}\right) W_{t} / U^{\prime}\left(w_{t}\right)$.

Similarly, in country 2 investors maximize $E\left(U^{*}\left(W^{*}{ }_{t+1}\right)\right)$ where $W^{*} t+1$ is given by:

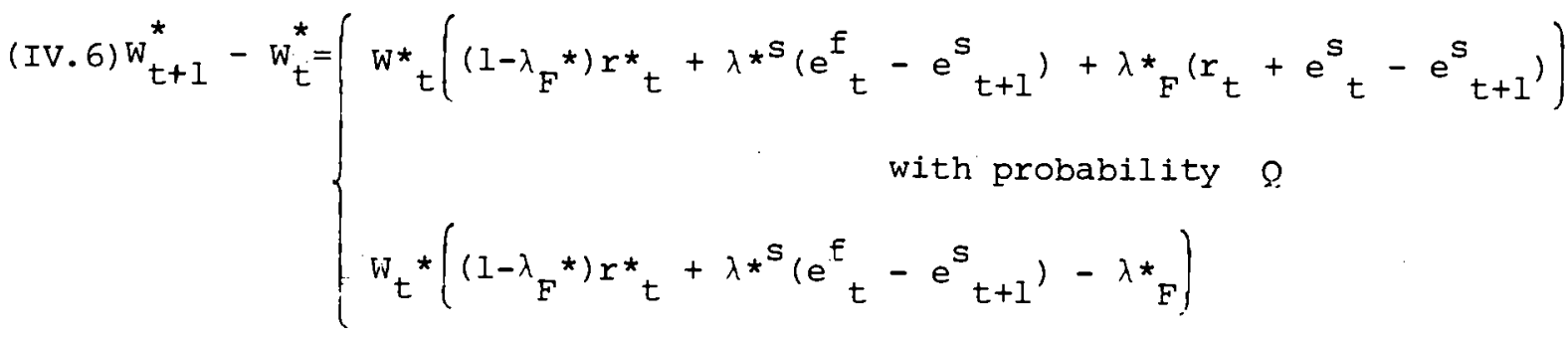

$$
\begin{aligned}
& \text { with probability } 1-\Omega \text {. }
\end{aligned}
$$

1 - $Q$ is the probability of country 1 defaulting on debts to country 2, $\lambda{ }^{*}$ is the share of country 2 's wealth invested in country 1 's bonds, and $\lambda *^{S}$ is the share of country 2 's wealth allocated to the forward sale of country I's currency.

This yields:

(IV. 7) $\lambda *^{s}=\frac{e_{t+1}^{s}-e^{f} t}{R \sigma_{e}^{2}}-Q \lambda *^{F}$.

(IV.8) $\lambda \star^{F}=\left(\bar{r}_{t}-r^{*}{ }_{t}\right)\left[R * Q(I-Q)\left(1+\sigma_{e}^{2}\right)\right]^{-1}$ 
with

(IV.9a)

$$
\bar{r}_{t}=\left(r_{t}+e_{t}^{s}-e_{t}^{f}\right) Q-(1-Q)
$$

$$
R^{*}=U^{* \prime}\left(W^{*}{ }_{t}\right) W^{*}{ }_{t} / U^{* \prime}\left(W^{*}{ }_{t}\right)
$$

Let $B_{t}$ the stock of country 1 bonds and $B^{*}{ }_{t}$ the stock of country 2 bonds. Market equilibrium in the two bond markets and in the forward market is given in (Valo-12). It is assumed that the initial distribution of wealth is as follows: residents of country 1 own a fraction $\alpha_{1}$ of the stock of domestic bonds and a fraction $\beta_{1}$ of the stock of foreign bonds.

$$
\begin{aligned}
& \left(1-\lambda^{F}\right)\left(\alpha_{1} B_{t}+\beta_{1} B_{t}^{*} \exp \left(e^{S}{ }_{t}\right)\right)+\lambda *^{F}\left(\left(1-\alpha_{1}\right) B_{t}+\left(1-\beta_{1}\right) B^{*}{ }_{t} \exp \left(e^{S}{ }_{t}\right)\right)=B_{t} \\
& \left.\lambda^{F}\left(\alpha_{1} B_{t}+\beta_{1} B^{*} t^{\exp \left(e^{S}\right.}{ }_{t}\right)\right)+\left(1-\lambda^{* F}\right)\left(\left(1-\alpha_{1}\right) B_{t}+\left(1-\beta_{1}\right) B^{*}{ }_{t} \exp \left(e^{s}\right)\right)=B_{t}^{*} \exp \left(e_{t}^{S}\right. \\
& \lambda^{S}\left(\alpha_{1} B_{t}+\beta_{1} B^{*} \exp \left(e_{t}^{S}\right)+\lambda^{* S}\left(1-\alpha_{1}\right) B_{t}+\left(1-\beta_{1}\right) B^{*}{ }_{t} \exp \left(e^{S}{ }_{t}\right)=0 .\right.
\end{aligned}
$$

The following conclusions can be drawn immediately:

a) If there is no risk of default $\left(Q=Q^{*}=1\right)$, market equilibrium requires interest parity: $r_{t}^{*}+e_{t}^{f}-e_{t}^{s}=r_{t}$.

b) If there is default risk $\left(0<Q, Q^{*}<1\right)$, but there is risk-neutrality $\left(\mathrm{R}=\mathrm{R}^{*}=0\right)$, market equilibrium might seem to require:

$$
\left(r_{t}^{*}+e_{t}^{f}-e_{t}^{s}\right) Q^{*}-\left(1-Q^{*}\right)=r_{t}
$$

and

$$
\left(r_{t}+e_{t}^{s}-e_{t}^{f}\right) Q-(1-Q)=r_{t}^{*} .
$$

The expected rate of retumfrom investing at home or abroad must be the same to the residents of any given country if they are to hold both domestic and foreign bonds; the common expected rate of return could, however, differ as between residents from different countries: there is "asymmetric" default risk for a given borrower vis à vis domestic and foreign lenders. What happens in fact is that at least one country's bond is held exclusively by that country's own residents: national capital markets become segmented. 
c) If there is default risk $\left(0<Q, Q^{*}<1\right)$ interest parity will not prevail, regardless of the presence or absence of risk aversion.

Note that in the presence of default risk, forward cover cannot fully eliminate exchange risk. Even if the forward contract is free of default risk, as we have assumed, not all exchange risk can be eliminated if, as we have assumed, the default risk is attached to an asset, that is denominated in terms of foreign exchange. If there is no exchange risk $i \sigma_{e}^{2}=0$, $e_{t}^{s}=e_{t+1}^{s}=e_{t}^{f}=e_{t}^{-f}$, , default risk alone is sufficient to prevent interest parity from being established. The forward rate will be an unbiased predictor of the future spot exchange rate $\left(e_{t+1}^{s}=e_{t}^{f}\right)$ if either there is no exchange risk or there is risk-neutrality.

IV.2. Risk, asymetric information and the 'Lemons Principle' in International Financial Markets

The 'Lemons Principle', due to Akerlof [1970] states that in markets with asymetric information between buyers and sellers (e.g. the buyer does not know the true quality of the goods he buys while the seller does), there exists an incentive for sellers to offer poor quality goods because both high and low quality goods sell at the same price. The result is a reduction in the average quality of the goods traded and a contraction in the size of the market. This analysis has been applied to credit markets by Jaffee and Russell [1976] who developed it into a theory of credit rationing and by Webb [1979] who uses it to refute Barro's public sector debt neutrality theorem (Barro [1974]). This section applies Jaffee and Russell's (J.R.) and Webb's analyses to international financial markets. For simplicity, exchange risk is abstracted from i.e. the analysis is set in a fixed exchange rate world which is confidently expected to stay that way. Consider a two-period world in which a large group of borrowing countries faces an international financial market in which lenders have access to funds at a constant rate of interest i. All borrowing countries have identical, non-stochastic income streams $\left(y_{1}, y_{2}\right)$ and identical preferences defined on 
consumption in the two periods $\left(c_{1}, c_{2}\right)$. Some countries, however, are "honest" and others "dishonest". Honest countries will not default in period 2 on their loans contracted in period 1 . Dishonest countries will default on their loans if default results in a higher value of second period consumption than repayment of the loan. In the absence of a penalty for default, $z$, dishonest countries will always choose to default. Note that default in this set-up is always discretionary, as income is non-stochastic. The model can be extended to allow for stochastic income streams. This results in 'unlucky' honest countries going into default as well as dishonest countries, whether 'lucky' or 'unlucky'. We are not concerned here with the fundamental determinants of discretionary (or dishonest) as opposed to unlucky default. These determinants may be entirely psychological, reflecting differences in national "tastes" for honesty, or they may reflect inter-country differences in the perceived cost of default, i.e. in the value of $z$. Eaton and Gersovitz [1979, 1980] provide an intaresting positive theoretical model of defaut behaviour and test it on a sample of LDC's.

There is assumed to be asymmetric information insofar as lenders cannot differentiate, in period 1, between honest and dishonest borrowers if both demand the same amount of loans, $L$, at any given borrowing rate, r.... If lenders could identify dishonest borrowers, they would be excluded from the market. $6 /$ Without such an exclusion rule, dishonest borrowers would always contract for the largest possible loan. With this exclusion rule, dishonest borrowers will duplicate or mimic the borrowing behavior of the honest borrowers. It is assumed that the solution to the two-period Fisherian intertemporal choice problem without default, involves a positive amount of borrowing which is the same for all borrowers (utility functions are strongly separable in consumption during the two periods and the 'propensity to default'). With first-period consumption chosen by all borrowers "as if" they were honest, and with utility an increasing function of consumption in both periods, the dishonest will default on loans if the value of second period consumption 
under default exceeds what it would be without default. With default second period consumption is $y_{2}-z$. Without default, second period consumption is $y_{2}-(1+r) L$, where $L$ is the size of the loan.

To characterize the market equilibrium that is generated by this asymmetric information structure we first derive the demand for and supply of loans.

The utility maximization programs of the honest borrower is given by equations (IV.13-15) - that of the dishonest borrower by (IV.16-19).

$$
\begin{aligned}
& \text { (IV.13) } \max _{c_{1}, c_{2}} u\left(c_{1}, c_{2}\right) \\
& \text { subject to: } \\
& \text { (IV.14) } \quad c_{1}=y_{1}+\bar{I} \\
& \text { (IV. 15) } \quad c_{2}=y_{2}-\bar{L}(I+r) \\
& \text { (IV.16) } \quad \max u\left(c_{1}, c_{2}\right) \\
& \mathrm{c}_{1}, \mathrm{c}_{2} \text {. } \\
& \text { subject to: } \\
& \text { (IV.17) } \quad c_{1}=y_{1}+\tilde{L} \\
& \text { (IV. 18) } \quad c_{2}=\max \left\{y_{2}-\tilde{L}\left(1+r_{2}, y_{2}-z\right\}\right. \\
& \text { (IV.19) } \overline{\mathrm{L}}=\tilde{\mathrm{L}}
\end{aligned}
$$

Given (IV.19), $\overline{\mathrm{L}}=\tilde{\mathrm{L}}=\mathrm{L}$, say, and the demand for loans by both types of borrowers is fully determined by the behavior of the honest ones, represented in (IV.13 - 15). This yields a demand function for loans, (IV.20) $\quad L^{d}=e^{d}\left(y_{1}, y_{2}, r\right)$

We only consider solutions involving borrowing, i.e. $L^{d}>0$. We assume that $\ell_{r}^{d}<0:$ an increase in the borrowing rate reduces the demand for loans. The substitution effect of a higher interest rate favours $\ell_{r}^{d}<0$, and the negative wealth effect of a higher interest rate on borrowers will also tend to reduce $c_{1}$ and thus $L$, if $c_{1}$ is a normal good. 
The supply of loans is derived from the risk-neutral expected profit maximizing behavior of lenders. Following Jaffee and Russell we assume that the cost of default varies among dishonest individuals. There are very high values of $z$, specifically $z>\frac{y 2}{1+r}$, for which no-one defaults. (Note that $\mathrm{Y}_{2}(1+r)^{-1}$ is the largest loan ever demanded by honest borrowers). We also assume there to be a minimum value of $z, z_{\min }$. For loans less than $\frac{z_{\text {min }}}{1+r}$ no-one defaults. Assume there is a continuous distribution function of dishonest borrowers by $z$ for values of $z$ above $z_{\min }$. The distribution of defaults then is a continuous function of $(1+r) L$ for values of $L>\frac{z_{\text {min }}}{1+r}$. Let $\Lambda=\lambda((1+r) L)$ be the probability that a loan is not defaulted on. $\lambda((1+r) L)=1$ for $(1+r) L<z_{\text {min }} \cdot \lambda((1+r) L)$ is a continuous function of $(1+r) L$ with $\lambda^{\prime}<0$ for $(1+r) L>z_{\text {min }}$. Expected profits, $\pi$, of the lending institutions are given by

(IV. 2I) $\quad \pi=(1+r) L \lambda((1+r) L)-(1+i) L$.

Assuming a competitive loan market with costless and instantaneous free entry, $\pi=0$, and the supply function for loans is given by:

$(I V .22)(1+r) \lambda((1+r) L)=1+i$.

For $L \leq \frac{z_{\min }}{1+r}, \Lambda=1$ and $r=i$. For $L>\frac{z_{\min }}{1+r}$ we have $\Lambda<1$ and $r>i$. Beyond knowing that for $L \leq \frac{z_{\min }}{1+r}, r=i$ and for $L>\frac{z_{\min }}{1+r}, r>i$, the slope of the supply schedule of loans, $L^{s}$, is ambiguous. $L^{s}=\ell^{s}(r, i)$ with $\ell_{r}^{s}=$ $-\frac{\left(\lambda+(1+r) \lambda^{\prime} L\right)}{(1+r)^{2} \lambda^{\prime}} \cdot$ This supply schedule will be upward-sloping if the elasticity of the $\lambda$ function with respect to $\lambda$ exceeds unity i.e. if $\frac{\lambda^{\prime}(1+r) L}{\lambda}>1 \cdot^{\frac{8}{}}$ For reasons of space this is the only case considered in what follows. The demand and supply schedules for loans are drawn in Figure IV.1. If, as drawn in Figure IV.I, the demand and supply schedules intersect at a value of $L>\frac{z_{\min }}{1+r}$, then $\lambda<1$ and $r>i$; the equilibrium borrowing rate exceeds the lenders' marginal cost of funds: honest borrowers pay a premium above the opportunity cost of funds, $1+i$, which subsidizes 
Figure IV.1

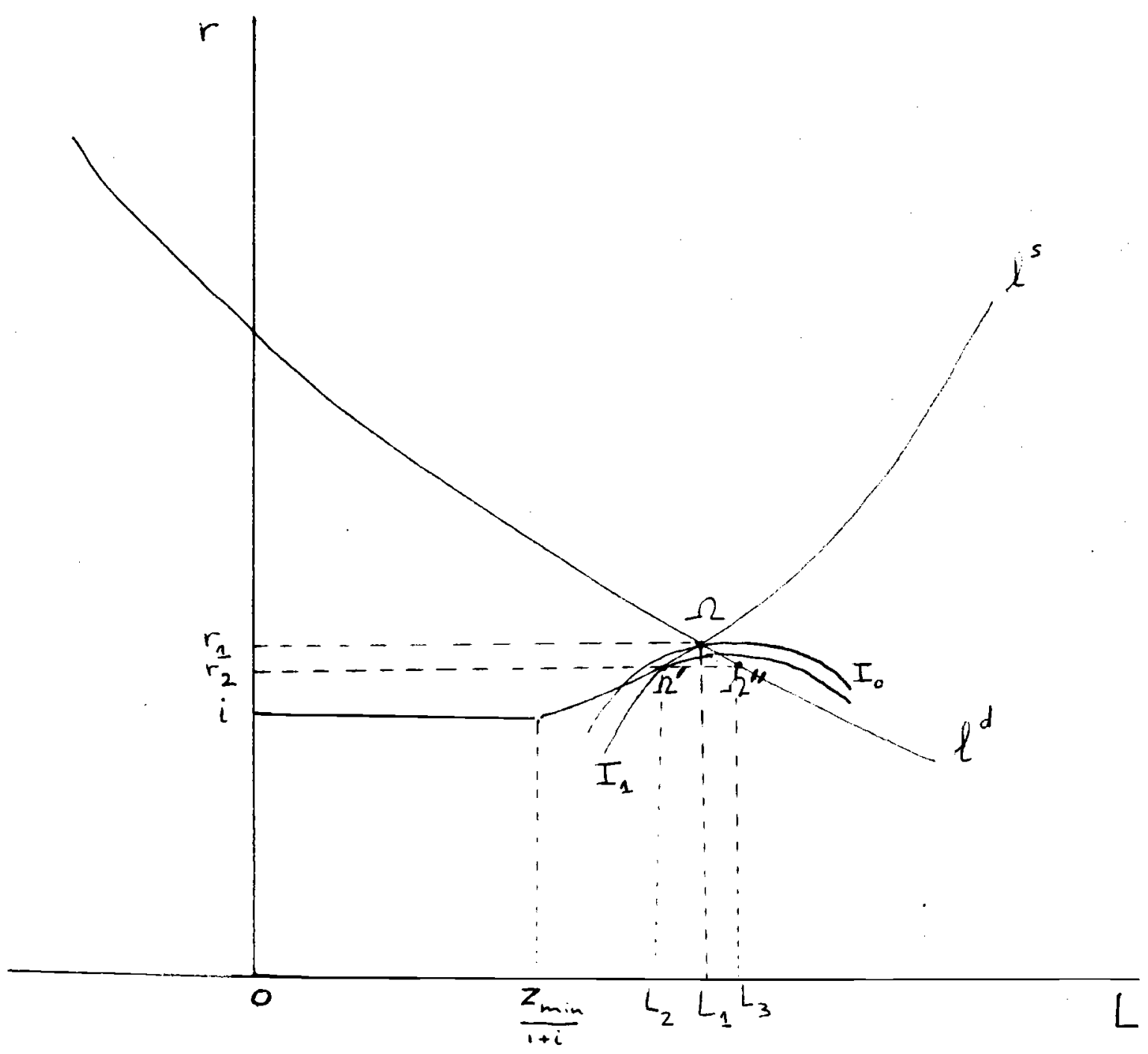


The application of the Jaffer-Russell model to international lending in the presence of discretionary default risk suggests the following proposition: Proposition IV.1. If the intemational financial market clears (we are at $\Omega$ in Figure IV.1), the presence of sovereign risk (discretionary default risk) can lead to the violation of interest parity: the borrowing rate, $r$, will be above the marginal cost of funds to the lender, $i$.

A second important potential departure from the efficient markets paradigm is that a strong case can be made for the existence of non-market clearing, rationing equilibria. The assumption of a competitive lending market with free entry is maintained. Suppliers are therefore always on a zero expected profit schedule. The assumption of mimicking behavior by dishonest borrowers is also maintained, and the $\Lambda$ function underlying the supply schedule $\ell^{\mathbf{S}}$ is therefore unchanged. Consider again the "normal" case of an upward-sloping $\ell^{S}$ schedule. Market clearing occurs at $\Omega$, the intersection of $\ell^{d}$ and $\ell^{s}$. Normal competitive pressures may appear to rule out any other position on the $\ell^{S}$ schedule as an equilibrium. At an interest rate below $r_{1}$ in Figure 3 there is excess demand for loans, putting upward pressure on $r$; an interest rate above $r_{1}$ there is excess supply and downward pressure on r. However, honest borrowers would prefer a rationing contract such as $\Omega^{\prime}$. Indifference curves in $r$ - $L$ space have the shape of $I_{0}$ and $I_{1}$ in Figure IV.I. They are horizontal where they intersect the demand schedule, with a negative slope to the right and a positive slope to the left of the intersection. They are strictly concave in the neighborhood of the intersection. Higher utility levels correspond to lower indifference curves. Given mimicking behavior by dishonest borrowers, $\mathrm{I}^{1}$ is the highest utility level that can be achieved by honest (and dishonest) borrowers. While they would prefer to borrow $\mathrm{I}_{3}$ at the interest rate $r_{2}$, honest borrowers prefer the rationed loan $\mathrm{L}_{2}$ at interest rate $r_{2}$ to the unrationed loan $L_{1}$ at $r_{1} \cdot 9 /$ Dishonest borrowers always prefer the larger loan but their preferences are not effective because they do not wish to reveal themselves. Consider the simple, and not implausible price- 
setting paradigm in which lenders set borrowing rates. If they offer the loan $L_{2}$ at the interest rate $r_{2}$ there will be excess demand for loans, but honest borrowers will never offer a higher interest rate than $r_{2}$ for a larger loan that can be supplied profitably by the lenders. Lenders could make positive profits for contracts above $\ell^{s}$ (ignoring free entry for the sake of argument), but every such contract is dominated by $\left(r_{2}, I_{2}\right)$ from the point of view of the honest borrowers. Contracts below $I^{l}$ are preferred by honest borrowers but cannot be supplied profitably. If lenders were to offer $\mathrm{I}_{2}$ at $r^{2}$, there are therefore no clear market forces at work which would cause lenders to change their behavior. At $\Omega^{\prime}$, there is no effective excess demand. It can therefore be viewed as a (Wilson) equilibrium. $10 /$ The implications for the modelling of international financial markets are summarized in proposition IV.2.

Proposition IV.2. In the presence of sovereign risk (discretionary default risk) international financial markets can be characterized by credit rationing. Even if a market-clearing interest rate-loan configuration exists, it is quite plausible that a non-market clearing, rationing equilibrium prevails.

IV.3. Other departures from market-efficiency associated with international asset risks

In the simple model of section IV.l the existence of default risk meant the demise of international interest parity. By itself, however, international interest parity is neither necessary nor sufficient for market efficiency • The Jaf fee-Russell model of Section IV.2 generated both an inefficient marketclearing equilibrium and a rationing equilibrium. Such a state of affairs is indeed inconsistent with the conventional notions of market efficiency outlined in Section III. The source of this inefficiency is information that is not merely incomplete, but unequally available to different market participants. Such a situation creates an incentive for obtaining additional information; country risk studies are an example of such effects. The often quite considerable costs in time, manhours and other resources involved 
in obtaining better information about potential borrowers' creditworthiness constitutes another departure from market efficiency. Such portfolio adjustment costs will impede the instantaneous ('stock-shift') rebalancing of portfolios in response to new information that characterizes the efficient markets models. Instead portfolios will be adjusted in a slower, gradual process. High information costs may also be reflected in "thin" markets, with a low volume of transactions. Indeed, certain markets (the U.S. Iranian loan market) may dry up altogether. Assets therefore become less "liquid". The assumption that each transactor acts as if he could dispose of his entire stock of foreign assets without affecting the price becomes untenable. This will make the markets less competitive.

Merely to point out that any or all of these effects may result from the existence of international asset risks is not to make a judgement as to their actual importance at a specific moment. If international asset risks are in fact negligible, the efficient markets model will be a reasonable description of reality. I believe that, merely on the basis of a quick review of recent historical events, it is safe to argue that actual international financial markets are affected frequently and significantly by actual or perceived international asset risks.

The existence of inefficient (especially quantity-constrained) equilibria means there is scope for policy intervention (foreign exchange market intervention, capital controls etc.) that is potentially welfare increasing. No serious study of the theory of second best as applied to inefficient international financial markets has to my knowledge been undertaken. The next section of the paper analyses some of the positive policy issues associated with the presence of international asset risks. The familiar ad hoc macromodel that is used is adequate for a narrow positive analysis of policy effectiveness, but does not permit a consideration of the normative issues. 
V. The implications of political risk for the international adjustment process with special emphasis on the scope for monetary policy: the rehabilitation of "imperfect capital mobility" and the non-horizontal BP Curve.

The first implication of international asset risk is that domestic and foreign assets no longer are perfect substitutes to the domestic investor, even if they are identical in all other respects, including currency denomination. Specifically, there no longer exists any foreign asset that is riskless to the domestic investor, even in terms of the currency in which it is denominated. The second implication of international asset risk is that rationing may occur; the supply of loans to an individual borrower (or country) is no longer perfectly elastic at parametric prices or rates of return. The third major implication is that transactions costs in international financial markets, especially the informational costs of evaluating the credit-worthiness of individual lenders and borrowers is raised significantly. This has significant implications for the investor's incentive (or indeed ability) to execute the instantaneous stock-shift changes in portfolio composition that are such an integral part of contemporary financial theory. I shall analyse the implications of international asset risk from the point of view of the authorities' ability to affect domestic interest rates. For reasons of space only monetary policy is considered. The effect of variations in the domestic money supply, brought about through open market purchases or sales of domestic government bonds on the domestic interest rate is analysed in three models. The first incorporates the assumption of perfect international credit markets and perfect substitutability of domestic and foreign assets. The second relaxes the assumption of perfect substitutability and replaces it by the assumption that domestic and foreign assets are gross substitutes. Foreign demand for domestic bonds also is no longer perfectly elastic at some exogenously determined rate of interest. Both models 1 and 2 maintain the assumption of negligible transactions costs: stock-shift changes in portfolio composition between domestic and foreign assets are both feasible and optimal. The third model assumes significant transactions costs for foreigners 
purchasing domestic bonds and domestic residents purchasing foreign bonds. These transactions costs are assumed to be such that stock-shift changes between domestic and foreign assets are never optimal. This requires that there be costs associated with the instantaneous rates of change of asset holdings. Lumpy transactions costs associated with finite changes in asset holdings would still permit instantaneous stock-shifts in portfolios.

\section{Notation}

A : domestic absorption

Y : domestic output

$\mathrm{X}$ : trade balance surplus

$\ell$ : demand for real money balances

$\mathrm{h}^{*}$ : foreign demand for domestic bonds

j : domestic demand for foreign bonds

W : private wealth

G : government spending

T : taxes net of transfers

M : nominal stock of money balances

B : nominal stock of domestic government bonds

$\mathrm{B}^{\mathrm{d}}$ : domestic holdings of domestic government bonds

$\mathrm{B}^{\mathrm{f}}$ : foreign holdings of domestic government bonds

$\mathrm{B}^{*}$ : domestic holdings of foreign bonds (denominated in foreign currency)

$\mathrm{R}^{*}$ : official foreign exchange reserves (denominated in foreign currency)

$r$ : interest rate on domestic bonds

$r^{*}$ : interest rate on foreign bonds

$\mathrm{p} \quad$ : price of domestic output

$\mathrm{p}^{*} \quad$ price of imports (in terms of foreign currency)

e : spot exchange rate (price of foreign exchange in terms of domestic currency)

$\mathrm{p} \quad$ : domestic and foreign cost-of-living index

$\delta$ : instantaneous stock-shift (differential) operator

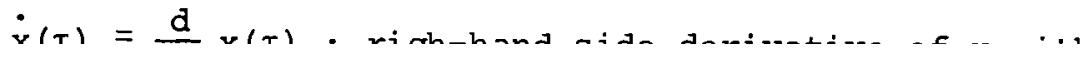


Mode1 1: A simple model without international asset risks.

The model is represented in equations V.l - V.12.

$$
\begin{aligned}
& \text { (V.I) } \quad A=Y-X \quad \text { (LM) } \\
& \text { (V.2) } \quad \ell=\frac{M}{\tilde{p}} \quad \text { (IS) }
\end{aligned}
$$

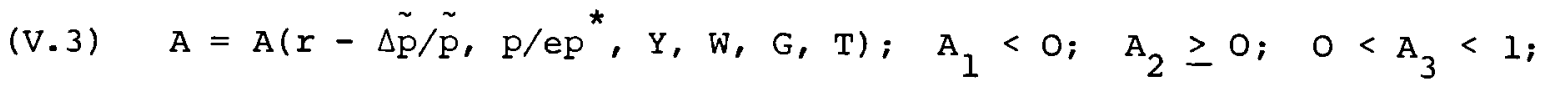

$$
\begin{aligned}
& A_{4}>0 ; \quad 0<A_{5} \leq 1 ; \quad-1<A_{6}<0 \\
& \text { (V.4) } \quad l=\ell(r, Y, W) \quad ; \quad \ell_{1}<0 ; \ell_{2}>0 ; 0<\ell_{3}<1 \text {. } \\
& \text { (V.5) } \quad \mathrm{X}=\mathrm{X}\left(\mathrm{r}-\Delta \tilde{\mathrm{p}} / \tilde{\mathrm{p}}, \mathrm{p} / \mathrm{ep}{ }^{*}, \mathrm{Y}, \mathrm{W}, \mathrm{G}, \mathrm{T}\right) ; \mathrm{x}_{1}>0 ; \mathrm{x}_{2}<0 ;-1<\mathrm{x}_{3}<0 \text {; } \\
& \mathrm{x}_{4}<0 ;-1<\mathrm{x}_{5}<0 ; 0<\mathrm{x}_{6}<1 \text {. }
\end{aligned}
$$

$(V .6) \quad W \equiv\left(M+B+e B^{*}\right) / \tilde{p}$

(V.7) $\quad r=r^{*}+\Delta e / e$

(V.8) $\quad \tilde{\mathrm{p}}=\mathrm{p}^{\alpha}\left(\mathrm{ep}^{*}\right)^{(1-\alpha)} \quad ; 0<\alpha<1$

To stay as close as possible to text-book practice I shall consider the "Keynesian" version of the model which has $Y$ endogenous and $p$, the price of domestic output as exogenously fixed. The model can of course be easily adapted to handle the "classical" case with $\mathrm{Y}$ fixed and $\mathrm{p}$ endogenous. $11 /$ For reasons of space only the fixed exchange rate case is considered. In model 1 it is assumed, without loss of generality for our purposes, that all domestic government debt is held by domestic residents. Capital formation is ignored, but could easily be included. The exogenous variables are p, $r^{*}, p^{*}, G$ and $T . \quad$ Predetermined variables are private net worth $M+B+e B^{*}$ and public sector net worth $e R^{*}-M-B$.

The instantaneous stock-shift constraints on changes in public and private sector portfolio composition are:

for the private sector

(V.9) $\delta M+\delta B+e \delta B * \equiv 0$

and for the public sector

$(V .10) \delta M+\delta B-e \delta R^{*} \equiv 0$. 
The continuous flow constraints are:

the balance of payments identity

(V.11) $\dot{\mathrm{BB}}^{*}+\mathrm{e}^{*} \equiv \mathrm{pY}+\mathrm{r}^{*} \mathrm{eB}^{*}-\mathrm{pA} \equiv \mathrm{pX}+\mathrm{r}^{*} \mathrm{eB}{ }^{*}$

and the government budget identity:

(V 12) $\dot{\mathrm{M}}+\dot{\mathrm{B}}-\dot{\mathrm{R}}^{*} \equiv \mathrm{pG}+\mathrm{rB}-\mathrm{pT}$.

In the Keynesian version under a fixed exchange rate, $\frac{\Delta \tilde{p}}{\tilde{p}}=\frac{\Delta e}{e}=0$.

The IM curve will be upward-sloping and with mild restrictions the IS curve will be downward-sloping. The horizontal line with intercept $r^{*}$ in Figure V.l is often referred to as the BP or balance of payments equilibrium schedule. It is of course no such thing. I shall refer to it as the EPB or external portfolio balance schedule. It shows the combinations of $r$ and $Y$ consistent with portfolio equilibrium as between the stocks of internal and external debt. The flow balance of payments equilibrium condition ( $V .11$ with $\dot{R}^{*} \equiv 0$ ) has no convenient graphical representation in $\mathrm{r}-\mathrm{Y}$ space. $\frac{12 /}{}$ The story of the ineffectiveness of monetary policy as regards the interest rate is familiar and follows immediatcly from equation $\dot{v} .7$ with $\Delta e=0$. An open market purchase of domestic bonds by an amount $\Delta$ will not result in an increase in $M$. Private agents will use the additional money to purchase foreign bonds to the tune of $\Delta_{i}$ in the process they return the increase in $M$ to the authorities in exchange for foreign exchange required to purchase the foreign bonds. The instantaneous result of this stock-shift portfolio rebalancing is an unchanged $M$, a reduction in $B$ by an amount $\Delta$, a reduction in $\mathrm{eR}^{*}$ by $\Delta$ and an increase in $\mathrm{eB}^{*}$ by $\Delta$. The interest rate and the level of output are unaffected. Domestic (and foreign) portfolio holders are indifferent between holding domestic and foreign bonds at the common, exogenous interest rate $r^{*}$ because they are assumed to have identical risk properties.

Model 2: A simple model with international asset risks but without transactions costs.

In this model domestic and foreign bonds no longer are perfect substitutes in private portfolios. With foreign assets perceived as risky by domestic residents and domestic assets viewed as risky by foreign residents, the domestic 
Figure V.I

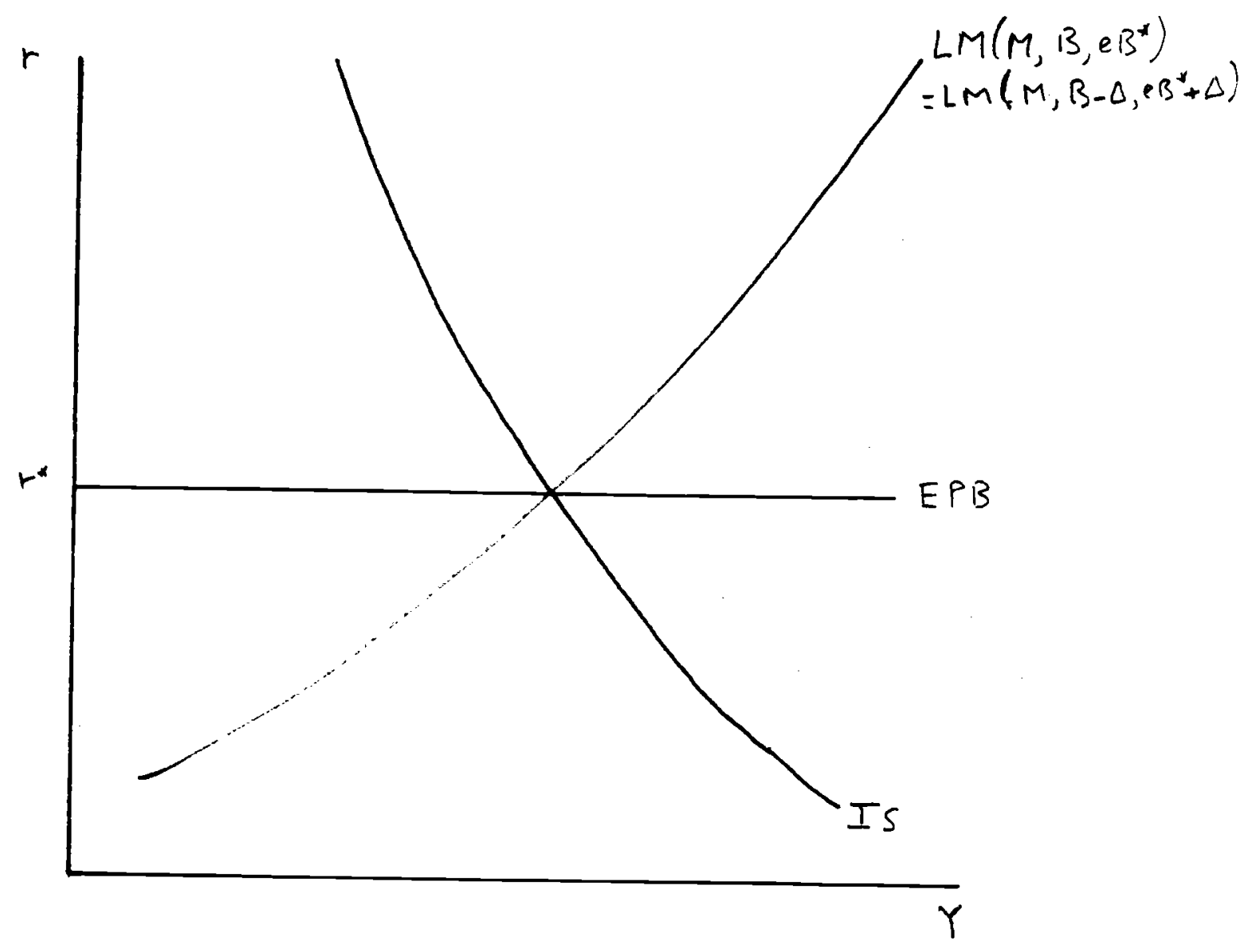


interest rate is no longer automatically equal to the foreign interest rate plus the forward premium on the foreign currency and a fortiori it will no longer be always equal to the foreign interest rate plus the expected rate of appreciation of the foreign currency. The model is summarized in equations IV.13 - IV.17.

(V.13) $\mathrm{A}\left(\mathrm{r}-\Delta \tilde{\mathrm{p}} / \tilde{\mathrm{p}}, \mathrm{r}^{*}+\Delta \mathrm{e} / \mathrm{e}-\Delta \tilde{\mathrm{p}} / \tilde{\mathrm{p}}, \mathrm{p} / \mathrm{ep}{ }^{*}, \mathrm{Y},\left(\mathrm{M}+\mathrm{B}^{\mathrm{d}}+\mathrm{eB}{ }^{*}\right) / \tilde{\mathrm{p}}, \mathrm{G}, \mathrm{T}\right)=$

$$
\begin{aligned}
& \mathrm{Y}-\mathrm{x}\left(\mathrm{r}-\Delta \tilde{\mathrm{p}} / \tilde{\mathrm{p}}, \mathrm{r}^{*}+\Delta \mathrm{e} / \mathrm{e}-\Delta \tilde{\mathrm{p}} / \tilde{\mathrm{p}}, \mathrm{p} / \mathrm{ep}{ }^{*}, \mathrm{Y},\left(\mathrm{M}+\mathrm{B}^{\mathrm{d}}+\mathrm{eB}{ }^{*}\right) / \tilde{\mathrm{p}}, \mathrm{G}, \mathrm{T}\right) . \\
& \mathrm{A}_{1}<0, \mathrm{~A}_{2}<0, \mathrm{~A}_{3} \geq 0,0<\mathrm{A}_{4}<1, \mathrm{~A}_{5}>0 ; 0<\mathrm{A}_{6} \leq 1,-1<\mathrm{A}_{7}<0 . \\
& \mathrm{x}_{1}>0 ; \mathrm{x}_{2}>0, \mathrm{x}_{3}<0,-1<\mathrm{x}_{4}<0 ; \mathrm{x}_{5}<0 ;-1<\mathrm{x}_{6}<0 ; 0<\mathrm{x}_{7}<1 .
\end{aligned}
$$

(V. 14) $\quad \ell\left(r, r^{*}+\Delta e / e, Y,\left(M+B^{\alpha}+e^{*}\right) / \tilde{p}\right)=M / \tilde{p}$

$$
l_{1}<0, l_{2}<0, l_{3}>0,0<l_{4}<1 \text {. }
$$

(V.15) j(r, $\left.{ }^{*}+\Delta e / e, Y,\left(M+B^{\alpha}+e B^{*}\right) / \tilde{p}\right)=e B^{*} / \tilde{p}$

$$
j_{1}<0 ; \quad j_{2}>0 ; \quad j_{3} \lesseqgtr 0 ; 0<j_{4}<1 \text {. }
$$

(v. 16) $h^{*}\left(r-\Delta e / e, r^{*}, \ldots\right)=B^{f} / \tilde{p}$.

(V. 17) $B^{f}+B^{d}=B$.

Without transactions costs each domestic or foreign investor acts as if, at parametric interest rates, existing portfolios can be reshuffled costlessly. The stock-shift constraint of the public sector is given as before by $(\mathrm{V} .10)$. The stock-shift constraint for the domestic private sector allows for the fact that some domestic bonds are held by the rest of the world, as given by $\left(\mathrm{V} \cdot 9^{\prime}\right)$.

$$
\left(V .9^{\prime}\right) \delta \mathrm{M}+\delta \mathrm{B}^{\mathrm{d}}+\mathrm{e}^{*} \mathrm{~B}^{*} \equiv 0
$$

Note that (V.10) and (V. ' ') imply:

$$
\text { (V.18) } \delta_{R}^{*}=\delta B^{f}-e \delta B^{*} \text {. }
$$

The continuous flow constraints are: the balance of payments identity $\left(\mathrm{V}\right.$ 19) $\dot{\mathrm{e}}^{*}+\dot{\mathrm{B}}^{*}-\dot{\mathrm{B}}^{f}=\mathrm{pY}+\mathrm{r}^{*} \mathrm{eB} \mathrm{B}^{*}-\mathrm{rB} \mathrm{f}^{f}-\mathrm{pA}=\mathrm{pX}+r^{*} \mathrm{eB}{ }^{*}-\mathrm{rB}$ and the government budget identity, which is the same as before (V.12). 
Equations (IV.14) and (IV.15) represent the domestic demand for money and the domestic demand for foreign bonds. The domestic demand for domestic bonds, $h$, is suppressed using the balance sheet constraint $\ell+h+j \equiv w \equiv(M+B d$ $\left.+e B^{*}\right) / \tilde{p}$. Money, domestic and foreign bonds are 'gross substitutes'. If the demand for money balances depends positively on income, $\ell_{Y}>0$, then $h_{Y}+j_{Y} \equiv$ $-\ell_{Y}<0$. Using (IV.16) and (IV.17) to substitute for $B^{d}$ and $B^{f}$, and assuming a fixed price level and a fixed exchange rate, we can summarize the monetary equilibrium as in equations (V.20, 21 and 22), choosing units such that $\mathrm{e}=\mathrm{p}=\mathrm{p}^{*}=1$.

$$
\begin{aligned}
& A\left(r, r^{*}, 1, Y, M+B-h^{*}\left(r, r^{*}, \ldots\right)+B^{*}, G, T\right)= \\
& Y-X\left(r, r^{*}, 1, Y, M+B-h^{*}\left(r, r^{*}, \ldots\right)+B^{*}, G, T\right)
\end{aligned}
$$

(V.21) $\quad\left(r, r^{*}, Y, M+B-h^{*}\left(r, r^{*}, \ldots\right)+B^{*}\right)=M$

(V.22) $j\left(r, r^{*}, Y, M+B-h^{*}\left(r, r^{*}, \ldots\right)+B{ }^{*}\right)=B^{*}$

The three endogenous variables are $r, Y$ and $B^{*}$ if the authorities choose to control M. Figure V.2 illustrates the effect of an increase in M brought about by an open-market purchase of domestic bonds by the government. With $M$ an instrument of government control, $B^{*}$ adjusts instantaneously to satisfy (V.22). Diagramatically $B^{*}$ adjusts to make the EPB schedule pass through the intersection of the IS and LM schedules. There is a different EPB schedule for every value of $B^{*}$. If $j_{Y}$ is positive, the EPB schedules will be upwardsloping, if it is negative it will be downward-sloping. If it is upwardsloping, a higher value of $\mathrm{B}^{*}$ shifts the EPB schedule to the right; if it is downward-sloping a higher value of $B^{*}$ shifts the EPB schedule to the left. Whether the EPB schedule is upward-sloping or downward-sloping, the effect of an increase in $M$ is to lower the domestic interest rate. The open market purchase of domestic bonds will, if the EPB schedule is upward-sloping (Figures V.2a and V. 2b) lead to a stock-shift outflow of capital. This stock-shift outflow is made up of a reduction in foreign holdings of domestic bonds $\left(B^{f}=h^{*}\left(r, r^{*}, \ldots\right)\right)$ 


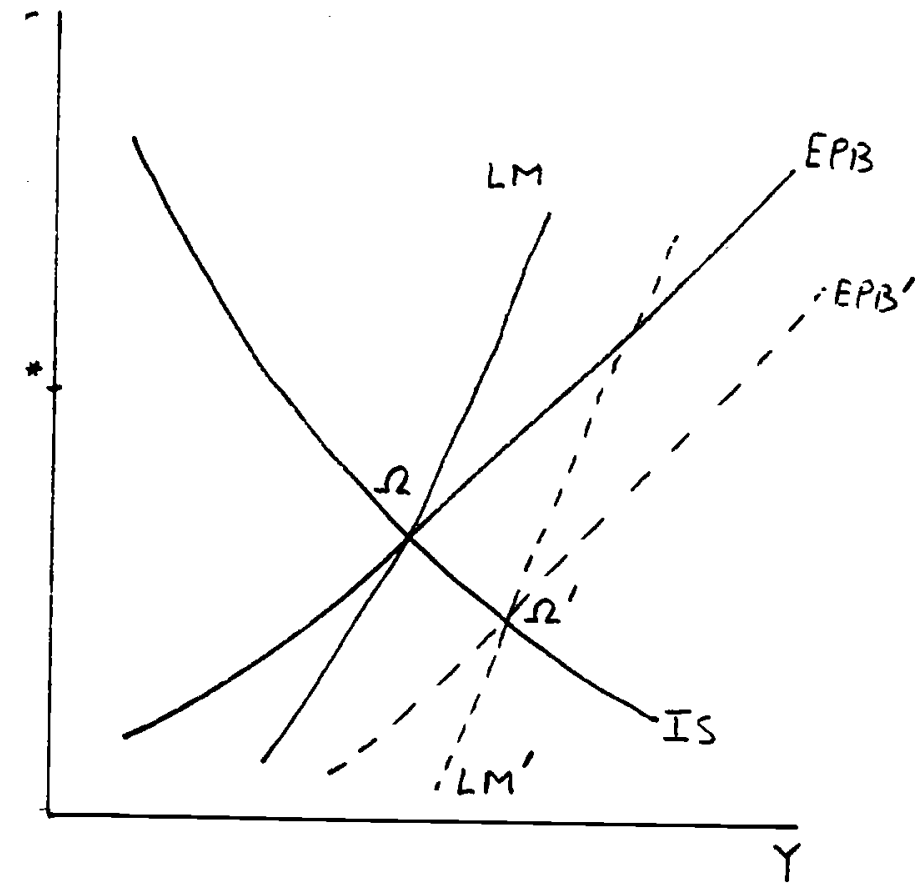

(a)

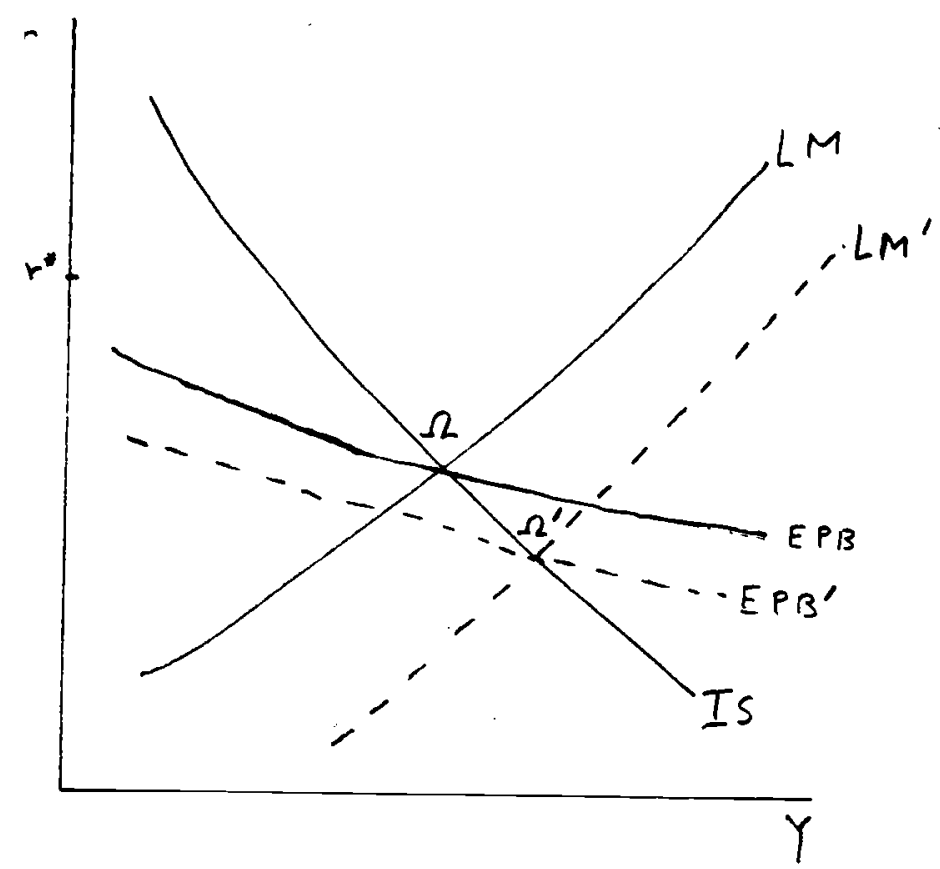

(c)
Figure V.2

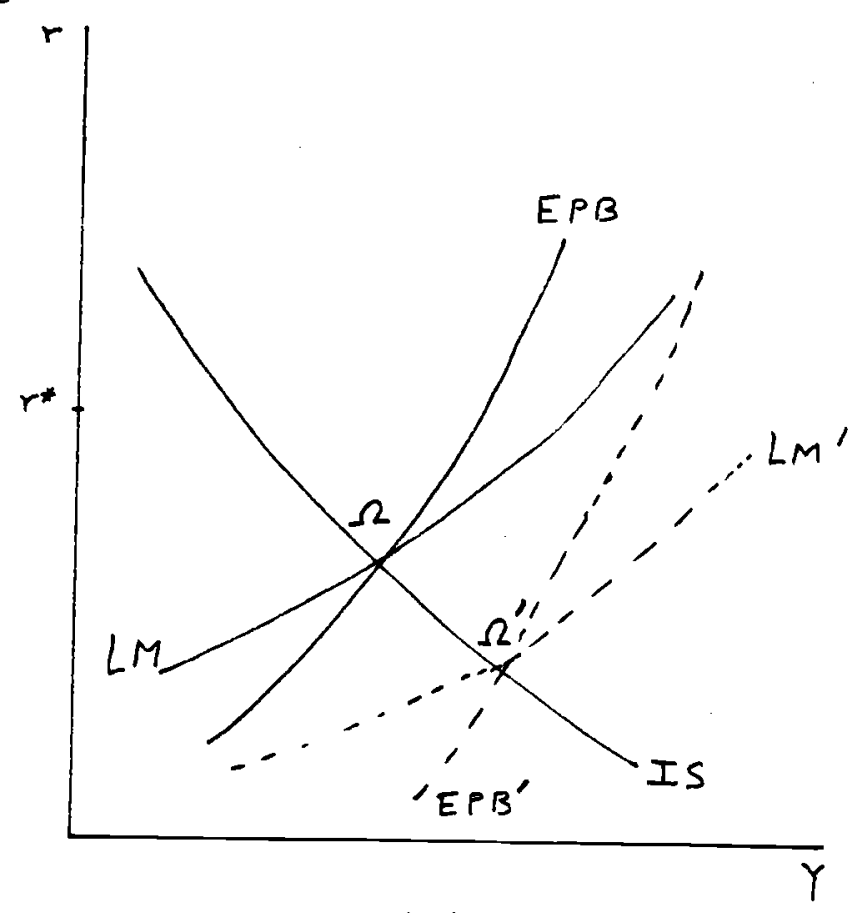

(d)

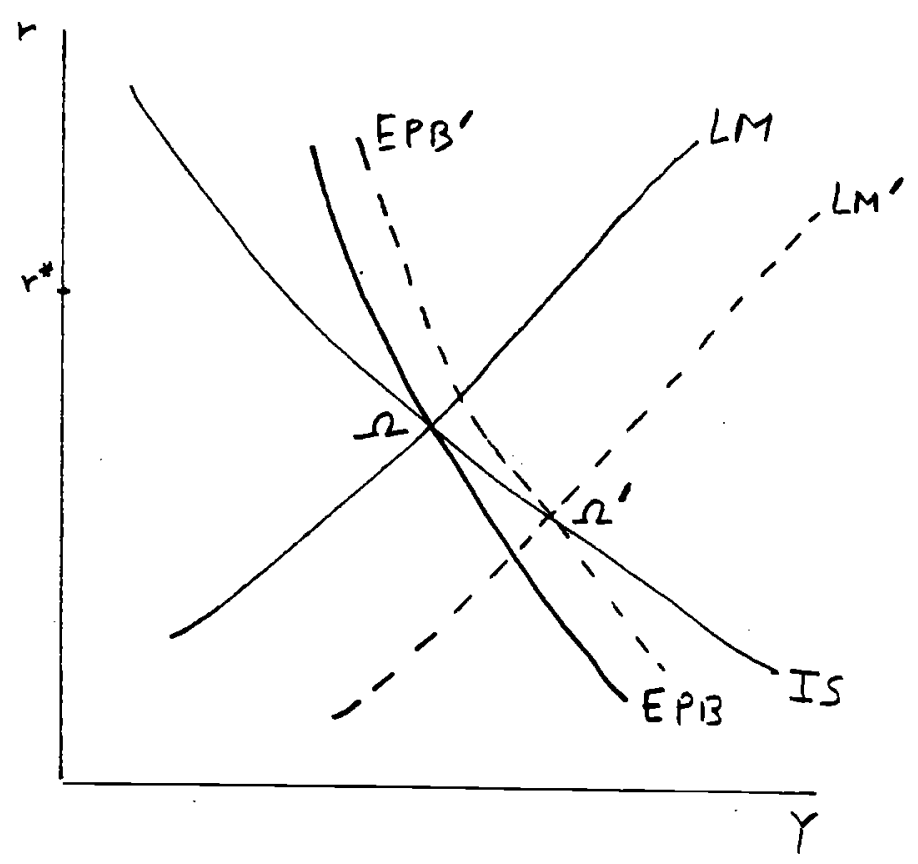

(d) 
and an increase in domestic holdings of foreign bonds $\left(B^{*}=j\left(r, r^{*}, Y, W\right)\right.$. Since domestic and foreign bonds are not perfect substitutes, domestic and foreign portfolio holders can only be induced to hold the smaller volume of domestic government debt by a decline in its interest rate. In Figures $\mathrm{V} .2 \mathrm{C}$ and V.2d the income effect on the domestic demand for foreign bonds is negative and the EPB schedule is downward-sloping. In V.2c, where the EPB schedule is less steep than the Is schedule the lowering of the domestic interest rate resulting from an open market purchase of domestic bonds is again accompanied by a stock-shift increase in domestic holdings of foreign bonds. In Figure V.2d the EPB schedule is steeper than the IS schedule, reflecting a very strong negative income effect on domestic demand for foreign bonds. In that case the lower $r$ and higher $Y$ resulting from an open market purchase of domestic bonds are accompanied by a stock-shift reduction in $\mathrm{B}^{*}$. There will still be a stock-shift reduction in $B^{f}$, but the combined effect on $B^{*}-B^{f}$ may well be a decline, i.e. there could be a stock-shift inflow of capital from abroad. Note that imperfect substitutability between domestic and foreign assets results from differences in risk-characteristics of investments among countries, whether these risk-characteristics are symmetric or not. Asymmetric political risk can make de facto imperfect substitutes out of assets whose "de-politicized" return distributions have identical risk properties.

Model 3: A simple model with international asset risks and portfolio adjustment costs.

As in the previous model, domestic and foreign bonds are no longer viewed as perfect substitutes, due to international asset risks. In addition it is now assumed that international asset risks lead to significant portfolio adjustment costs in international financial markets. These costs are to be thought of primarily as informational. In the presence of adjustment costs or other transactions costs, which we shall view as increasing functions of the instantaneous rates of change of asset stocks, it will never be optimal to engage in instantaneous stock-shift changes in holdings of assets that are subject to such costs. In our model this means that instantaneous stock-shift changes in domestic portfolios between $M$ and $B$ are possible, but not between 


$$
\text { - 35- }
$$

therefore always have the dimension of continuous instantaneous rates of change with respect to time. The literature on optimal capital accumulation in the presence of adjustment costs shows that in general the optimal investment functions will be complicated functions of the initial state and the current and expected future values of all variables that are viewed as parametric by the optimizing agent. If we assume that domestic and foreign bonds have identical "de-politicized" risk characteristics, model 3 can be viewed as closest to the asymmetric political risk case, i.e. risk depending on the country of habitat of the lender or borrower. If transactions costs (including information costs) are not an increasing function of the rate of change of asset holdings, stock-shift changes in portfolio composition would occur whenever exogenous parameter changes or disturbances of a certain minimum size occur. For simplicity I shall assume that the "asset accumulation functions" describing the portfolio behaviour of domestic and foreign residents can be represented by simple partial stock adjustment functions based on the no-adjustment costs asset demand functions $j$ and $h^{*}$ specified in $(V .15)$ and (V.16). $\frac{13 /}{}$ The model can now be described by equations (V.13), (V.15), (V.17) and:

$$
\frac{\mathrm{d}}{\mathrm{dt}}\left(\frac{\mathrm{B}^{\mathrm{f}}}{\tilde{\mathrm{p}}}\right)=\Psi^{*}\left(\mathrm{~h}^{*}\left(r-\Delta \mathrm{e} / \mathrm{e}, \mathrm{r}^{*}, \ldots\right)-\frac{\mathrm{B}^{\mathrm{f}}}{\tilde{\mathrm{p}}}\right) \quad \Psi^{* \prime}>0 ; \psi^{*}(0)=0 .
$$

$$
\frac{\mathrm{d}}{\mathrm{dt}}\left(\frac{\mathrm{eB}}{\tilde{\mathrm{p}}}\right)=\Psi\left(j\left(r, r^{*}+e / e, Y,\left(M+\mathrm{B}^{\mathrm{d}}+\mathrm{eB}^{*}\right) / \tilde{\mathrm{p}}\right)-\frac{\mathrm{eB}^{*}}{\tilde{\mathrm{p}}}\right) \psi^{\prime}>0 ; \quad \Psi(0)=0 .
$$

No stock-shift changes in $\mathrm{B}^{*}$ will ever be optimal, therefore

(V.25) $\delta M+\delta B d \equiv 0$.

There also will be no stock-shift change in $\mathrm{R}^{*}$.

In the presence of "internal" portfolio adjustment costs there is no EPB function. The historically given stocks of $B^{*}$ and $B^{f}$ are always "willingly held". There is, however, a well-defined flow balance of payments equilibrium schedule or $B P$ curve in $r-Y$ space. Since $\dot{e}^{*}=p X+r^{*} e B^{*}-r B^{f}-e \dot{B}^{*}+\dot{B}^{f}$, we can, using $(\mathrm{V} .23)$ and $(\mathrm{V} .24)$ derive the locus of $r$ and $Y$ pairs for which $\dot{\mathrm{R}}^{*}=0$. For the case in which $\mathrm{e}$ and $\mathrm{p}$ are constant, and setting $\mathrm{e}=\mathrm{p}=\mathrm{p}^{*}=1$, this gives:

(V.26) $X\left(r, r^{*}, 1, Y, M+B-B^{f}+B^{*}, r=m \perp n_{n}^{*} \ldots F^{*}\right.$ 
The slope of this schedule is given by:

$$
\left.\frac{d r}{d Y}\right|_{B P}=\frac{\Psi^{\prime} j_{3}-x_{4}}{\Psi^{* \prime} h_{1}^{*}-\Psi^{\prime} j_{1}+x_{1}-B^{f}} .
$$

In the denominator the "capital inflow" effects of an increase in the interest rate $\psi^{*}{ }^{\prime}{ }_{1}^{*}-\Psi^{\prime} j_{1}$ are positive and will be reinforced by a possible effect of interest rates on import demand $\left(x_{1}>0\right)$. A higher interest rate will, however, increase the cost of servicing the outstanding volume of foreign-owned domestic debt. Only if this effect is not too significant will the denominator of (V.27) be positive. An increase in domestic income will worsen the trade balance $\left(x_{4}<0\right)$. If it increases the (long-run) stock demand for foreign bonds $\left(j_{3}>0\right)$ the flow capital account will also be adversely effected. If $j_{3}<0$, the increase in $Y$ would improve the capital account. In the 'textbook case' both numerator and denominator are positive and the BP curve is upwardsloping, as in Figure V.3. The initial equilibrium at $\Omega$ is assumed to be a position of balance of payments equilibrium. An increase in M via an open market purchase of domestic bonds shifts the LM curve to the right, lowers $r$ and raises $Y$. The balance of payments moves into disequilibrium. The interest rate falls because no instantaneous stock-shift change in portfolio composition is possible. A lower interest rate is required to make domestic bond holders willing to hold a smaller stock of domestic bonds. Figure v.3 a.iso incorporates the current. account equilibrium schedule, $C A$, whose equation is given by:

(V.28) $X\left(r, r^{*}, 1, Y, M+B-B^{f}+B^{*}, G, T\right)+r^{*} B^{*}-r B^{f}=0$.

Its slope is given by

$$
\left.\frac{d r}{d Y}\right|_{C A}=\frac{-X_{4}}{X_{1}-B^{f}}
$$

Unless $B^{f}$ is very large this will be upward-sloping. Unless $j_{3}$ is very large and positive the $C A$ curve will be steeper than the $B P$ curve. In Figure V.3 the initial momentary equilibrium $\Omega$ was also assumed to be a position of current account equilibrium. The momentary equilibrium after the open market purchase at $\Omega^{\prime}$ is therefore also a position of current account 


$$
\text { - } 37-
$$

Figure V.3

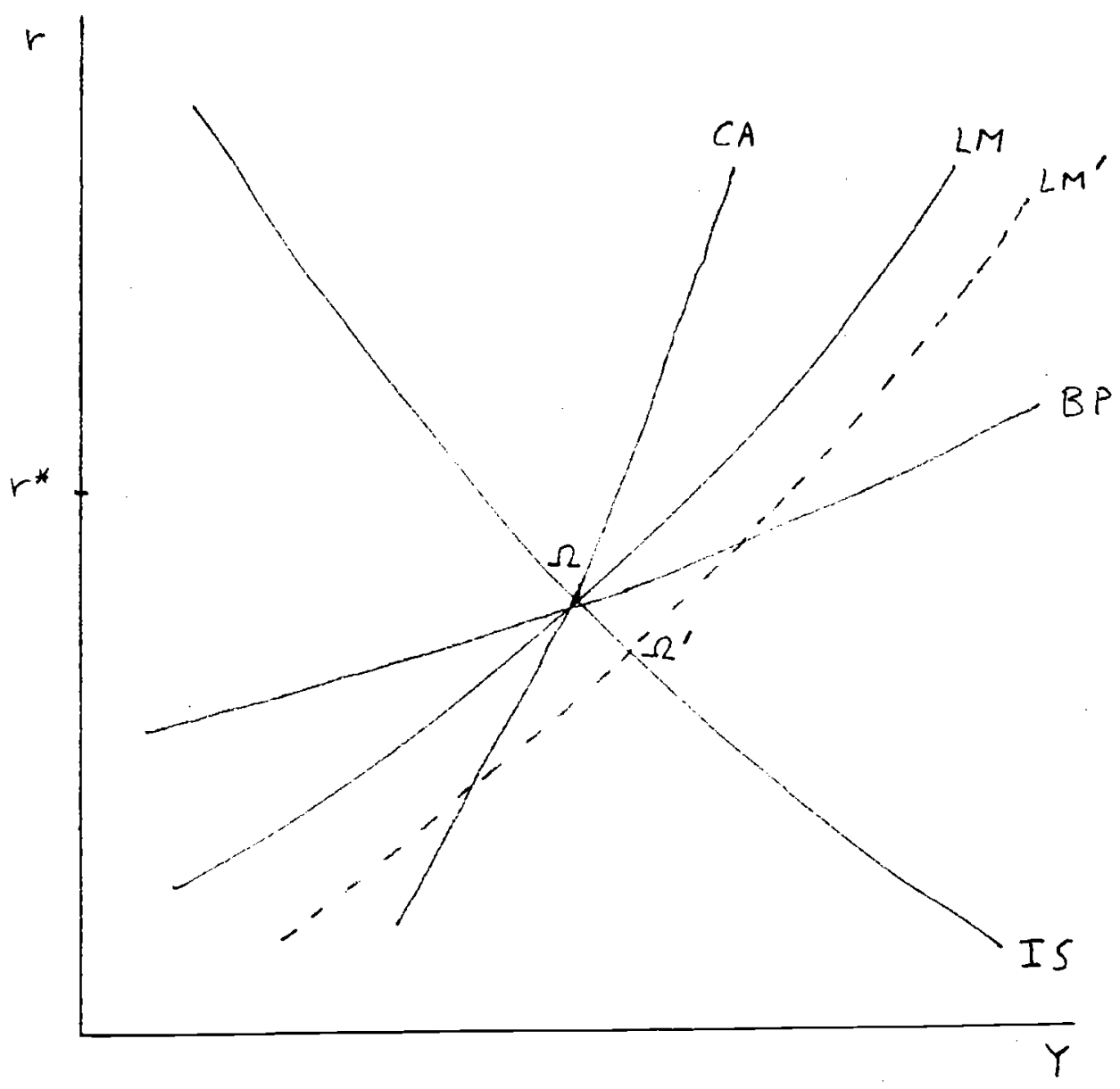


In the limit, as transactions costs go to zero and $\psi^{\prime \prime}$ and $\psi^{* \prime}$ tend to infinity together, model 2 re-emerges and the slope of the BP curve tends to the slope of the EPB schedule for a given value of $B^{*}:\left.\frac{d r}{d Y}\right|_{E P B}=\frac{j_{3}}{h_{1}^{*}-j_{1}}$. When domestic and foreign bonds in addition are perfect substitutes $\left(h_{1}^{*}=+\infty, j_{1}=-\infty\right),\left.\frac{d r}{d Y}\right|_{E P B}=0$ which is the case of model 1 . For $\Omega$ to be a full (stationary) equilibrium it is in addition necessary that $h^{*}=B^{f}, j=B^{*}$ and that the govermment does not run a deficit or surplus nor engages in 'continuous flow' open market operations $(\dot{M}=-\dot{B})$. Given a policy function or financing rule to determine $\dot{M}$ and $\dot{B}$, we can trace the full dynamic adjustment of the model as described by the behavior over time of the four state variables, $B, B^{*}, M$ and $B^{f}$. This analysis is omitted here for reasons of space. Also, it makes little sense to study long-run asset stock adjustment while maintaining the short-run assumption of sticky prices.

\section{Conclusion}

International asset risk implies that domestic and foreign loans cease to be perfect substitutes in private portfolios, even if they are denominated in the same currency and are identical in all other respects. The main implication for the international adjustment process is that even small, financially open countries regain control over domestic interest rates. Without international asset risks domestic interest rates were independent of domestic monetary and fiscal policy actions (other than asymmetric tax treatment of domestic and foreign bond income) under a fixed exchange rate regime. With market-determined exchange rates domestic policy actions could only alter domestic interest rates by changing the forward discount or premium. In the presence of international asset risks, domestic policy affects domestic interest rates even under a fixed exchange rate regime. For this conclusion to emerge it is not necessary that 
there be transactions costs or other adjustment costs associated with changes in international portfolios. All that is required is that domestic and foreign bonds be perceived as imperfect substitutes and that world demand for the domestic bond is less than perfectly elastic. Stock-shift portfolio rebalancing will take place but is not carried to the point that all government-initiated changes in portfolio composition are arbitraged away. If international asset risks cause international financial markets to become significantly less 'perfect' and portfolio adjustment costs rule out instantaneous stock-shift changes in portfolio composition, the much-maligned flow balance of payments and the non-horizontal BP curve can reclaim a measure of respectability. 
" * I would like to thank Robert Stern and Clas Wihlborg for detailed written comments on an earlier version of the paper. Financial support from an N.S.F. Research Grant is gratefully acknowledged.

\section{FOOTNOTES}

1) Citicorp, 1975, Amual Report, New York, p. 18.

2f Citicorp, 1975, Annual Report, New York, p. 18.

3) Mc.W. Wolfe, [1975], p. 35

4f From 1967 to 1975 debt to the private markets of 86 country governments on which the World Bank reports has quadrupled. Even after allowing for inflation this represents a sizeable real increase (see Eaton and Gersovitz, [1979, 1980]).

5/ These conditions are (see Frankel [1979]): 1) All assets are nominal assets (money and bonds) whose returns are riskless in terms of their currency of issue, or else -- if there are other assets -- their real returns are independent of currency values. 2) All nominal assets are "inside" assets.

6/ Section II reviewed some of the ways in which lenders evaluate the default risk of prospective borrowers through "risk analysis". As long as borrowers retain information about their own default risk that is superior to lender information, the analysis goes through. of course, with honest borrowers in a "lucky-unlucky" model, the lender's expertise may well give him information about the borrower's default prospects that is superior to the information that is available to the borrower. Note that this is not the Eaton-Gersovitz model. They assume that all borrowers are potentially dishonest. All will default if the returns exceed the costs.

7/ For convenience, the lendina institutions are assumed not to recover anv 
8/ Jaffee and Russell show that if $\Lambda$ has the Pareto distribution and if the mean of this distribution does not exist, then the supply curve will be positively sloped for $r>i$. If it has the exponential distribution it will be backward-bending. The supply of loans relation need not be single-valued: it could be a correspondence rather than a function. Jaffee and Russell rule out multiple equilibria through the assumption that $\Lambda$, the proportion of borrowers who do not default, rises with $r$ along the demand curve and declines with $r$ along the supply schedule. The assumption about the demand curve is equivalent to $c_{1}$ and $c_{2}$ being 'gross substitutes': an increase in $r$ increases $c_{2}$; this amounts to a greater than unitary elasticity of loan demand with respect to the interest rate.

9/ I assume that the rationing rule is non-stochastic. Each borrower is provided with a certain loan of $\mathrm{L}_{2}$ at an interest rate $\mathrm{r}_{2}$. If the rationing rule were stochastic, risk-averse borrowers would derive a lower level of utility than $I_{1}$ from a random loan rationing rule with expected value $\mathrm{L}_{2}$ at an interest rate of $r_{2}$.

10/ The same conclusion emerges even more forcefully when the backward-bending supply schedule case is considered.

11/ If labour supply depends on the real wage in terms of $\tilde{p}$ and labour demand on the real wage in terms of $p$, the output supply schedule is an increasing function of $\frac{p}{\mathrm{ep}^{*}}$, even in the classical model as long as labour supply is not completely inelastic with respect to the real wage. 
12/ Flow balance of payments equilibrium is given by

$$
\begin{aligned}
& \dot{e}^{\star}=\operatorname{pX}\left(r, \frac{p}{e p^{\star}}, Y, \frac{M+B+e B^{*}}{\check{p}}, G, T\right)+r^{*} e B^{*} \text {. From the LM } \\
& \text { function (V.2) we find } \dot{\mathrm{B}}^{*}=\frac{-\tilde{\mathrm{p}}}{\ell_{3}}\left(\ell_{1} \dot{\mathrm{r}}+\ell_{2} \dot{\mathrm{Y}}+\left(\ell_{3}-1\right) \frac{\dot{\mathrm{M}}}{\tilde{\mathrm{p}}}+\ell_{3} \frac{\dot{\mathrm{B}}}{\tilde{\mathrm{p}}}\right) \text {. }
\end{aligned}
$$

13/ This kind of partial adjustment function will only be optimal if costs of adjustment are quadratic and expectations are static. 
Bibliography

Akerlof, G.A. "The Market for 'Lemons': Quality Uncertainty and the Market Mechanism," Quarterly Journal of Economics, 84, August 1970, pp. 488-500.

Aliber, Robert $z$. "The Interest Parity Theorem: A Reinterpretation," Journal of Political Economy, 81, Nov./Dec. 1973, pp. 1451-1460. "Exchange Risk, Political Risk and Investor Demand for External Currency Deposits," Joumal of Money, Credit and Banking, 7, 1975, pp. 161-179. Exchange Risk and Corporate International Finance, Macmillan, 1978, London.

Barro, Robert J. "Are Government Bonds Net Wealth?", Journal of Political Economy, 82, Nov./Dec. 1974, pp. 1095-1117.

Bench, Robert R. "Bank Problems in L.D.C. Lending." Paper given at the

AMR International/Euromoney Conference, Financing the L.D.C.'s,

The Role of the Euromarkets, Grosvenor House, London, October 11, 1977.

Bergsten, C. Fred. "Statement before the subcommittee on taxation and debt management of the Senate Finance Committee," Feb. 5, 1979.

Blask, Jerome $K$. "A Survey of Country Evaluation Systems in Use," Policy Analysis Staff Paper, Export Import Bank, Washington D.C., Dec. 1976.

Citicorp. 1975 Annual Report, New York.

Eaton, J. "A Stochastic Equilibrium Model of Exchange Rate Determination and Monetary Policy with Rational Expectations," Unpublished, Princeton, 1978 . and Mark Gersovitz,"Debt with Potential Reproduction: Theoretical and Empirical Analysis," Princeton University mimeo, 1979. ,"L.D.C. Participation in International Financial Markets: Debts and Reserves," forthcoming in the Joumal of Development Economics, 1980.

Export-Import Bank of the U.S., Policy Analysis Staff, "Memorandum on an Early Warning Model," August 22, 1977, and Appendix: "Minimum Quantitative/Qualitative Country Evaluation Information to be Developed for Foreign Public Sector Credit Review Committee Meetings." Feder, G. and R. Just, "A Study of Debt Servicing Capacity Applying Logit Analysis," Journal of Development Economics, March 1977.

Federal Reserve Bank of Boston, "Key Issues in International Banking," Boston, 1977.

Figlewski, Stephen. "Market 'Efficiency' in a Market with Hetergeneous Information," Journal of Political Economy, 86, August 1978, 
Fisk, C. and F. Rimlinger, "Non-Parametric Estimates of L.D.C. Repayment Prospects," Journal of Finance, Papers and Proceedings, May 1979.

Frank, C. and W. Cline, "Measurement of Debt Servicing Capacity: an Application of Discriminant Analysis," Juurnal of International Economics, Feb. 1971 .

Frankel, Jeffrey A. "The Diversifiability of Exchange Risk," Journal of International Economics,

Freeman, Richard "Optimal International Borrowing with Default," Federal Reserve Board International Finance Discussion Papers, No. 129, Jan. 1979 .

Goodman, Stephen "How the Big U.S. Banks Really Evaluate Sovereign Risks," Euromoney, February 1977.

Grossman, Sanford "On the Efficiency of Competitive Stock Markets where Traders have Diverse Information," Journal of Finance, 31, May 1976, pp. 573-586.

Harberger, Arnold C. "On the Determinants of Country Risk," Paper prepared for the University of Chicago--Department of State Project on the International Economic System, Dec. 1976.

Hellwig, Martin "A Model of Borrowing and Lending with Bankruptcy," Econometrica, Nov. 1977.

International Monetary Fund Annual Report, Exchange Arrangements and Exchange Restrictions, 1979, Washington D.C., 1979.

Jacque, Laurent L. Management of Foreign Exchange Risk, Lexington Books, D.C. Heath, 1978.

Jaffee, Dwight M. and Thomas Russell,"Imperfect Information, Uncertainty and Credit Rationing," Quarterly Journal of Economics, 90, Nov. 1976.

Kenen, P.B. "Trade, Speculation, Aid and the Forward Exchange Rate" in R. Baldwin et al. Trade, Growth and the Balance of Payments, North Holland, Amsterdam, 1965.

Kouri, P.J.K. "The Determinants of the Forward Premium," Institute for International Economic Studies Seminar Paper No. 62, Stockholm, August 1976.

Maroni, Yves "Approaches for Assessing the Risk Involved in Lending to Developing Countries," Federal Reserve Board International Finance Discussion Paper, No. 112, Nov. 1977.

Mc. W. Wolf, Jr., Alexander "Country Risk," in John F. Mathis (ed.) Offshore Lending by U.S. Commercial Banks, Philadelphia: Bankers' Association for Foreign Trade and Robert Morris Associates, 1975. 
Nagy, P. "Quantifying Country Risk: A System Developed by Economists at the Bank of Montreal," Colombia Journal of World Business, Fall, 1978.

Puz, Richard "How to Find Out when a Sovereign Borrower slips from Al to E5", Euromoney, August 1978.

Sargen, Nicholas "Economic Indicators and Country Risk Appraisal," Federal Reserve Bank of San Francisco Economic Review, Fal1, 1977.

Schuler, Harold D. "Evaluation of Risk in International Lending: $F$ Bank Examiner's Perspective." Paper given at the Federal Reserve Bank of Boston Conference on Key Issues in International Banking, October $5-7,1977$.

Webb, David C. "Are Government Bonds Net Wealth when Credit Markets are Imperfect," University of Bristol mimeo, October 1979.

Wihlborg, Clas "Risks, Capital Market Integration and Monetary Policy under Different Exchange Rate Regimes," Institute for International Economic Studies, Stockholm, Monograph No. 7, 1976. Currency Risks in International Financial Markets, Princeton Studies in International Finance No. 44, Decembsr 1978.

Zuheir, Sofia. A. External Debt of Developing Countries; Its Applization to Country Risk Analysis, The Huntington National Bank, 1978. 